\title{
Characterisation of particulate matter at a high-altitude site in southwest India: Impact of dust episodes
}

\author{
P Buchunde ${ }^{1,2}$, P D Safai ${ }^{1} *$, S Mukherjee ${ }^{1}$, P P LeEna $^{1}$, D Sinngh ${ }^{1}$, \\ G S Meena ${ }^{1}$ and G Pandithurai ${ }^{1}$ \\ ${ }^{1}$ Indian Institute of Tropical Meteorology, Pune 411 008, India. \\ ${ }^{2}$ Department of Atmospheric and Space Sciences, Savitribai Phule, Pune University, Pune, India. \\ *Corresponding author.e-mail: pdsafai@tropmet.res.in
}

MS received 21 November 2018; revised 20 June 2019; accepted 24 June 2019

Observations on a particulate matter $\left(\mathrm{PM}_{10}\right.$ and $\left.\mathrm{PM}_{2.5}\right)$ were carried out during March 2015 to February 2017 over a high-altitude location Mahabaleshwar in the Western Ghats region in southwest India. Apart from temporal variation of $\mathrm{PM}$ and the ratio of $\mathrm{PM}_{2.5} / \mathrm{PM}_{10}$, impacts of local meteorological parameters on the concentration of $\mathrm{PM}$ are examined. $\mathrm{PM}_{10}$ showed a maximum concentration during pre-monsoon, whereas $\mathrm{PM}_{2.5}$ showed it in winter. The monsoon season showed the lowest concentrations for both $\mathrm{PM}_{10}$ and $\mathrm{PM}_{2.5}$. Concentrations were significantly reduced in 2016 due to the washout effect from enhanced rainfall during that year. Diurnal variations of PM were related to the variation in a planetary boundary layer, mountain valley winds as well as changes in different local sources. Dominance of primary particles was observed from the $\mathrm{PM}_{2.5} / \mathrm{PM}_{10}$ ratio. The Central Pollution Control Board (CPCB) threshold limit for PM was exceeded on several days mainly during pre-monsoon due to transported dust from the Arabian Peninsula and Thar Desert apart from an increase in the tourist activity. A typical case for transported dust event during March 2016 is studied. Organics and sulphate particles showed a significant enhancement during dust event. Overall, the study indicated emissions from mixed sources for PM from local as well as distant source regions over Mahabaleshwar.

Keywords. $\mathrm{PM}_{2.5}$ and $\mathrm{PM}_{10}$; diurnal and seasonal variation; meteorological parameters; dust event; long-range transport; concentration weighted trajectories.

\section{Introduction}

Characterisation of atmospheric aerosols which are also termed as particulate matter (PM) poses a great challenge due to their variation in terms of spatial and temporal scales. Primary aerosols are directly injected into the atmosphere, while secondary ones are generated from gas-to-particle conversion mechanisms (Khemani 1989; Safai et al. 2010). PM constitutes one of the most challenging problems in terms of both air quality and climate change policies. Sources of PM include all types of Published online: 05 September 2019 combustion, such as emission from motor vehicles, power plants, residential wood burning, forest fires, agricultural burning, industrial processes and construction and demolition activities. Aerosols play a major role in several atmospheric phenomena such as air pollution, acid deposition, visibility degradation, radiation balance, precipitation formation, etc. (Khemani 1989). PM is one of the major urban air pollutants and it has been related to cardiovascular diseases and strokes (Burnett et al. 2014; Du et al. 2016), respiratory disorders, pulmonary diseases (Song et al. 2014) and even cognitive 
problems (Weuve et al. 2012). It has also been associated with millions of premature deaths annually (WHO 2016). Size and chemical composition of PM are the important factors affecting the air quality at any location. Transport of $\mathrm{PM}_{2.5}$ from regional and/or distant sources also contributes to the local air quality (van Donkelaar et al. 2010). From the health point of view, penetration of particles into the respiratory tract is a function of the particle size and the ratio of $\mathrm{PM}_{2.5} /$ $\mathrm{PM}_{10}$ is very critical. The high $\mathrm{PM}_{2.5} / \mathrm{PM}_{10}$ ratio attributes emission from combustion activities and the formation of secondary pollutants in the atmosphere. On the other hand, low $\mathrm{PM}_{2.5} / \mathrm{PM}_{10}$ ratios are related to more contribution from primary sources such as influx of dust or sea salt.

So far studies on fine sized $\mathrm{PM}\left(\mathrm{PM}_{2.5}\right.$, i.e., $\mathrm{PM}$ $\leq 2.5 \mu \mathrm{m})$ and coarse sized $\mathrm{PM}\left(\mathrm{PM}_{10}\right.$, i.e., $\mathrm{PM}$ $\leq 10 \mu \mathrm{m})$ are reported mainly for urban locations in India (Rengarajan et al. 2011; Tiwari et al. 2012, 2013; Panicker et al. 2015; Pipal and Satsangi 2015; Gawhane et al. 2017). Very few studies are reported from high-altitude stations in India (Safai et al. 2005; Chatterjee et al. 2010; Satsangi et al. 2014; Leena et al. 2017). Satsangi et al. (2014) have reported mean concentration of $\mathrm{PM}_{10}\left(35.8 \pm 15.2 \mu \mathrm{g} \mathrm{m}^{-3}\right)$ and $\mathrm{PM}_{2.5}\left(14.1 \pm 8.2 \mu \mathrm{g} \mathrm{m}^{-3}\right)$ at Sinhagad (1450 m above mean sea level (AMSL), a rural high-altitude location in the Western Ghats mountainous region during November 2008 to April 2009. Chatterjee et al. (2010) reported $\mathrm{PM}_{2.5}$ and $\mathrm{PM}_{10}$ over Darjeeling (2200 m AMSL), a high-altitude site in Eastern Himalayan ranges during January-December 2005. They reported $\mathrm{PM}_{2.5}$ dominated during dry seasons and $\mathrm{PM}_{10}$ dominated during monsoon. Similarly, a long-range transport of dust aerosol from arid regions of Western India was observed during pre-monsoon. Leena et al. (2017) have reported variation of PM at Mahabaleshwar during 2012-2013 and its relationship with gaseous pollutants as well as prevailing meteorological parameters. The present paper examines the temporal variation of $\mathrm{PM}_{2.5}$ and $\mathrm{PM}_{10}$ at Mahabaleshwar during March 2015-March 2017. Exceedances of Central Pollution Control Board (CPCB) threshold limits for $\mathrm{PM}_{10}$ and $\mathrm{PM}_{2.5}$ are reported. Diurnal and seasonal variations of weatherrelated parameters such as temperature, wind direction (WD), wind speed (WS) and humidity and their impact on variation of $\mathrm{PM}$ are also studied. The possible long-range transport of $\mathrm{PM}$ is examined using air mass back trajectories for different seasons. In addition to it, observations of omega winds, concentration weighted trajectories (CWTs) and NCEP winds have been used to ascertain the source regions during the dust event day.

\section{Sampling location, meteorology and methodology}

\subsection{Sampling location}

Mahabaleshwar $\left(17.92^{\circ} \mathrm{N}, 73.65^{\circ} \mathrm{E}, 1348 \mathrm{~m}\right.$ AMSL $)$ is a beautiful hill station surrounded by forests in the midst of Sahyadri mountain ranges in the Western Ghats region in southwest India. It is $120 \mathrm{~km}$ south of Pune which is one of the important urban centres in India. Observations were conducted at the High Altitude Cloud Physics Laboratory (HACPL) at Mahabaleshwar. Figure 1 shows the location of Mahabaleshwar on the map of India and the sampling site in the inset. The site is also a popular weekend gateway especially more during pre-monsoon. Figure 2 shows the number of visitors and vehicles visiting Mahabaleshwar since 2007-2016 annually. Vehicular and visitor count data during this period over Mahabaleshwar were obtained from the Nagar Parishad, Mahabaleshwar which shows a linear increase in both visitors and vehicles in the last one decade. Nearly 1 million tourists and 0.12 million vehicles visited Mahabaleshwar in 2007 whereas in 2016, about 2 million tourists and 0.33 million vehicles visited the hill station. The pre-monsoon season, especially during weekends recorded highest tourist influx.

\subsection{Local meteorology}

During the study period, meteorological data for major parameters such as temperature, relative humidity $(\mathrm{RH})$, WS and direction and rainfall were obtained using an automatic weather station (AWS) at a sampling rate of $1 \mathrm{~min}$. The statistical details of the observed meteorological parameters are shown in table 1 . To describe the seasonal trends, the $\mathrm{PM}_{10}$ and $\mathrm{PM}_{2.5}$ mass concentrations were categorised into pre-monsoon (March-May), Monsoon (June-September), post-monsoon (October-November) and winter (December-February). During pre-monsoon, north-westerly winds were dominant, whereas westerly/north-westerly winds mainly prevailed during monsoon. South-easterly winds were dominant during post-monsoon and winter seasons. 


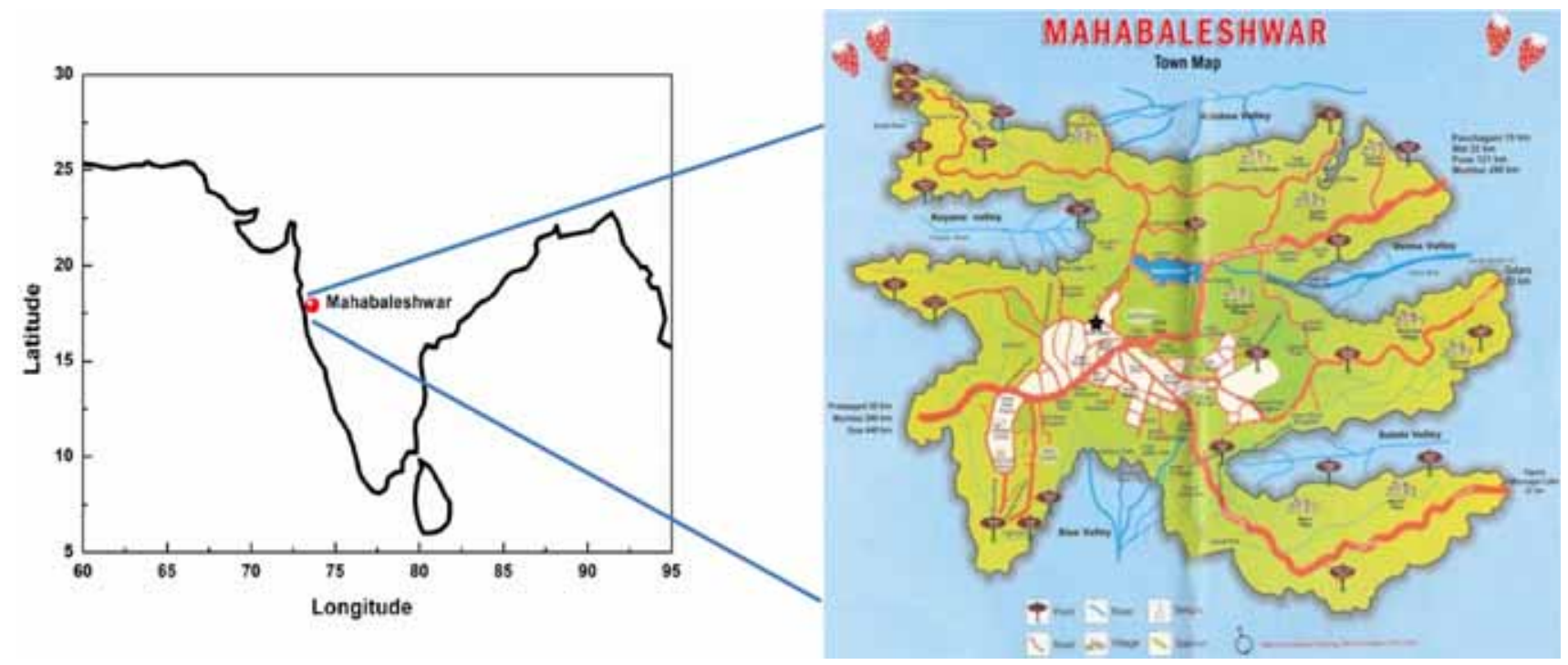

Figure 1. Location of Mahabaleshwar on the map of India and the sampling site in the inset.

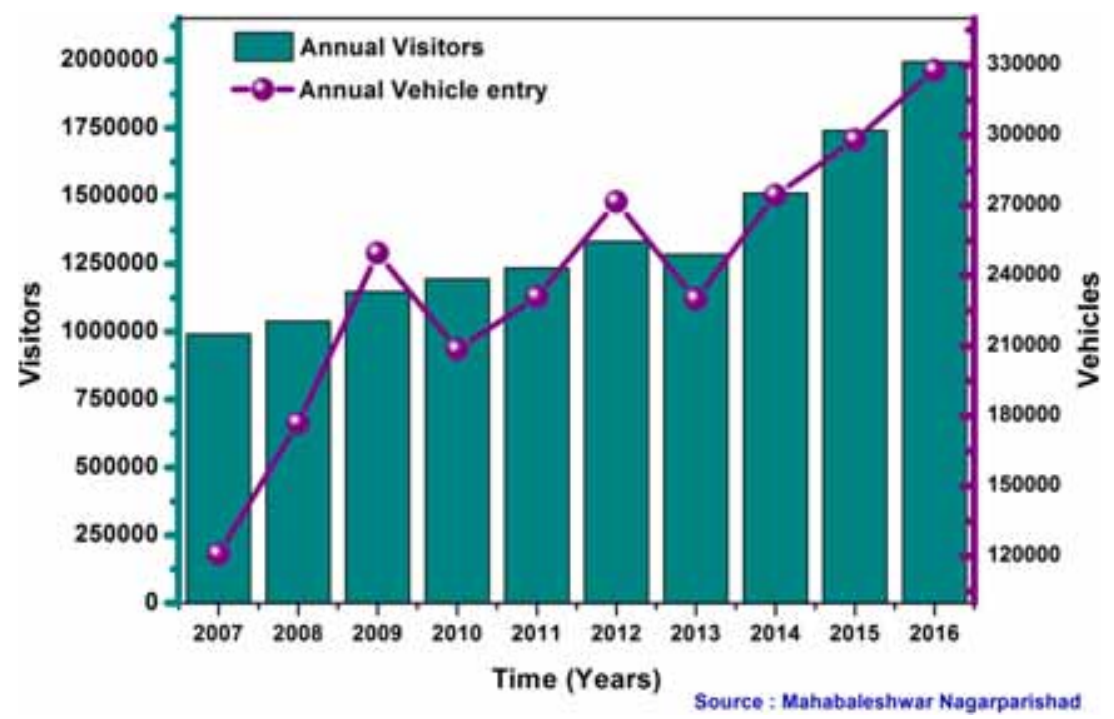

Figure 2. Annual number of visitors and vehicles that visited Mahabaleshwar during 2007 to 2016.

\subsection{Methodology}

Measurements on mass concentration of airborne PM were carried out using GRIMM Environmental Dust Monitor (EDM 180) from GRIMM Aerosol Technik, Germany. The operating principle of this equipment involves measurement of scattering of laser beam at a wavelength of $655 \mathrm{~nm}$ by particles passing through it. After amplification, the scattered light at $90^{\circ}$ is passed through a diode and then categorised into different sized channels. The EDM measures between 0.25 and $32 \mu \mathrm{m}$ diameters in discrete 31 channels. The reproducibility varies $\pm 3 \%$ of the total measuring range and it is online calibrated with a in-built temperature and humidity sensor for air density flow rate calculation. The sample flow rate of $1.2 \mathrm{l} / \mathrm{min}, \pm 3 \%$ constant due self-regulation is maintained and data are obtained at every $5 \mathrm{~min}$ interval. The equipment has an isothermal inlet with an integrated Nafion dryer that allows the use of a dehumidification system above $70 \% \mathrm{RH}$ to remove humidity from the sample pipe to get rid of any condensation during the measurement. Gravimetric and optical calibration of the equipment is performed every year. A study conducted by the Stockholm University, Sweden for the Swedish Environmental Protection Agency during 2012 has reported that 
Table 1. Statistical details of the meteorological parameters during the period of observations at Mahabaleshwar.

\begin{tabular}{|c|c|c|c|c|c|c|c|c|}
\hline \multirow[b]{2}{*}{ Parameter } & \multicolumn{2}{|c|}{ Pre-monsoon } & \multicolumn{2}{|c|}{ Monsoon } & \multicolumn{2}{|c|}{ Post-monsoon } & \multicolumn{2}{|c|}{ Winter } \\
\hline & 2015 & 2016 & 2015 & 2016 & 2015 & 2016 & 2016 & 2017 \\
\hline \multicolumn{9}{|c|}{ Temperature: ${ }^{\circ} \mathrm{C}$} \\
\hline Mean (SD) & $25.10(0.67)$ & $25.31(1.35)$ & $19.89(1.44)$ & $19.21(1.0)$ & $21.37(1.0)$ & $19.21(1.0)$ & $20.77(2.61)$ & $20.92(1.37)$ \\
\hline Maximum & 25.86 & 26.34 & 21.88 & 20.23 & 20.65 & 20.23 & 18.37 & 21.89 \\
\hline Minimum & 24.23 & 23.77 & 15.56 & 18.06 & 22.09 & 18.06 & 23.57 & 19.95 \\
\hline \multicolumn{9}{|l|}{ RH: \% } \\
\hline Mean (SD) & $92.98(8.90)$ & $95.67(1.45)$ & $92.98(8.90)$ & $95.67(1.45)$ & $68.17(5.83)$ & $65.75(13.7)$ & $43.72(9.14)$ & $52.6(18.7)$ \\
\hline Maximum & 99.76 & 97.09 & 99.76 & 97.09 & 72.30 & 75.47 & 52.63 & 97.7 \\
\hline Minimum & 81.11 & 93.75 & 81.11 & 93.75 & 64.05 & 56.05 & 34.36 & 10.2 \\
\hline \multicolumn{9}{|c|}{ Wind speed: $\mathrm{m} \mathrm{s}^{-1}$} \\
\hline Mean (SD) & $3.10(0.47)$ & $2.84(0.19)$ & $3.36(1.02)$ & $3.50(0.70)$ & $3.95(1.09)$ & $3.31(0.87)$ & $2.94(0.81)$ & $3.65(0.87)$ \\
\hline Maximum & 3.56 & 3.06 & 4.87 & 4.35 & 3.18 & 3.94 & 3.85 & 4.62 \\
\hline Minimum & 2.56 & 2.682 & 2.70 & 2.65 & 4.71 & 2.69 & 2.29 & 2.92 \\
\hline $\begin{array}{l}\text { Total } \\
\text { rainfall: } \mathrm{mm}\end{array}$ & 194 & 38.5 & 3776 & 6735 & 173 & 176.5 & 10 & 7 \\
\hline
\end{tabular}

results from Grimm EDM 180 evaluated against the reference sampler equipped with an US-EPA inlet showed $<20 \%$ uncertainty (ACES 2012).

During a particular dust event in pre-monsoon, the mass spectra of non-refractory submicron PM $\left(\mathrm{NR} \mathrm{PM}_{1}\right)$ were recorded using a time of flight aerosol chemical speciation monitor (ToF-ACSM). The chemical speciation of $\mathrm{NR} \mathrm{PM}_{1}$ which vaporises at about $600^{\circ} \mathrm{C}$ and $10^{-7}$ mbar was achieved by analysis of fragmentation patterns (Allan et al. 2004). More details on this instrument are discussed elsewhere ( $\mathrm{Ng}$ et al. 2011; Frohlich et al. 2013; Singla et al. 2017).

An AWS was used to monitor the meteorological conditions prevailing over the observational site such as WD, WS, temperature (T), RH and rainfall (R). Also we have used a National Oceanic and Atmospheric Administration (NOAA) Hybrid Single Particle Lagrangian Integrated Trajectory (HYSPLIT) model (Draxler and Rolph 2003) to obtain air-mass back trajectories. These back trajectories were used to infer the possible distant sources of the PM.

\section{Results and discussion}

\subsection{Monthly variation of $P M$ and $P M_{2.5} / P M_{10}$ ratio}

Figure 3 depicts the mean monthly mass concentration of $\mathrm{PM}_{10}$ and $\mathrm{PM}_{2.5}$ during the entire study period along with the ratio of $\mathrm{PM}_{2.5}$ to $\mathrm{PM}_{10}$. Analysis of $\mathrm{PM}$ data showed that in 2015, the maximum concentration for $\mathrm{PM}_{10}\left(81.37 \pm 17.43 \mu \mathrm{g} \mathrm{m}{ }^{-3}\right)$ was observed in April and that for $\mathrm{PM}_{2.5}$ $\left(48.49 \pm 9.58 \mu \mathrm{g} \mathrm{m}^{-3}\right)$ was observed in March. In the year 2016, the highest concentration for $\mathrm{PM}_{10}$ was observed in March $\left(62.92 \pm 26.12 \mu \mathrm{g} \mathrm{m}^{-3}\right)$, whereas for $\mathrm{PM}_{2.5}\left(46.86 \pm 16.82 \mu \mathrm{g} \mathrm{m}^{-3}\right)$ it was observed in February. The minimum concentration was observed in August of 2016 with $2.87 \pm 1.39 \mu \mathrm{g} \mathrm{m}^{-3}$ for $\mathrm{PM}_{10}$ and $2.85 \pm 1.38 \mu \mathrm{g} \mathrm{m}^{-3}$ for $\mathrm{PM}_{2.5}$. In 2015, the minimum was observed in the month of July with $5.96 \pm 3.88 \mu \mathrm{g} \mathrm{m}^{3}$ for $\mathrm{PM}_{10}$ and $4.86 \pm 2.46 \mu \mathrm{g} \mathrm{m}^{-3}$ for $\mathrm{PM}_{2.5}$. Concentrations of both $\mathrm{PM}_{10}$ and $\mathrm{PM}_{2.5}$ showed a decrease in 2016 than those in 2015. As seen from figure 2 , the number of visitors and vehicles increased in 2016 than those in 2015 which should have resulted in an increase in PM load. However, there seems to be a competing effect of more rainfall scavenging that countered and overcame the increase in the anthropogenic source of PM in terms of visitors and vehicles resulting in a net decrease in PM load over the study location during 2016.

The observed concentrations of $\mathrm{PM}_{10}$ and $\mathrm{PM}_{2.5}$ at Mahabaleshwar are compared with those reported for other similar sites in India and elsewhere (table 2). It is seen that $\mathrm{PM}_{10}$ concentrations at Mahabaleshwar were comparable with those reported at some other high-altitude locations like Lhasa, Sinhagad and Darjeeling, whereas $\mathrm{PM}_{2.5}$ was more at Mahabaleshwar than that reported at these locations. However, $\mathrm{PM}_{10}$ and $\mathrm{PM}_{2.5}$ concentrations at Mahabaleshwar were comparatively less than those reported at Kathmandu, Nepal which is almost at the same altitude like Mahabaleshwar. Also, concentrations of $\mathrm{PM}_{10}$ 


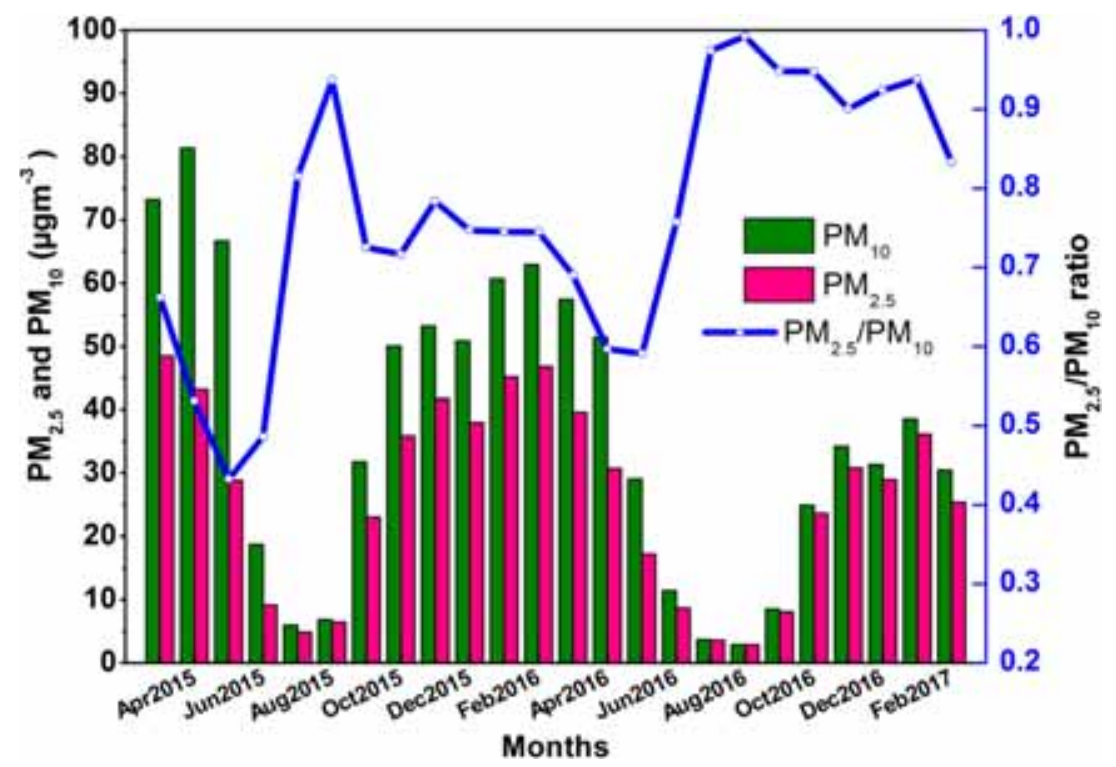

Figure 3. Mean monthly mass concentration of $\mathrm{PM}_{10}$ and $\mathrm{PM}_{2.5}$ during March 2015 to February 2017 along with the ratio of $\mathrm{PM}_{2.5}$ to $\mathrm{PM}_{10}$.

and $\mathrm{PM}_{2.5}$ were much higher at other urban locations than those observed at Mahabaleshwar which is quite expected. Sreekanth et al. (2018) have reported $\mathrm{PM}_{2.5}$ concentrations over five metro cities in India. They have reported the annual mean ( \pm standard deviation) concentrations of $\mathrm{PM}_{2.5}$ as $37 \pm 17,51 \pm 23,54 \pm 36,80 \pm 67$ and $114 \pm 86 \mu \mathrm{g} \mathrm{m}^{-3}$ over Chennai, Hyderabad, Mumbai, Kolkata and Delhi, respectively. The annual mean $\mathrm{PM}_{2.5}$ concentration at Mahabaleshwar during 2015-2016 (31 $\left.\pm 16.3 \mu \mathrm{g} \mathrm{m}^{-3}\right)$ and 2016-2017 $\left(21.3 \pm 12.9 \mu \mathrm{g} \mathrm{m}^{-3}\right)$ is found to be comparatively less than the above-mentioned values for five metro cities in India. Carrico et al. (2003) studied the PM over the Kathmandu valley, Nepal (Nagarkot 2150 m AMSL) from December 1998 through October 2000 and found higher $\mathrm{PM}_{2.5}$ $\left(59 \pm 61 \mu \mathrm{g} \mathrm{m}^{-3}\right)$ in February to May and lower during June to September with a steady increase during October to January $\left(25 \pm 14 \mu \mathrm{g} \mathrm{m}^{-3}\right)$. They have also suggested the possible effect of long-range transport of desert dust to the Himalaya from arid regions ranging from India and the Middle East or even from the Sahara along with the Kathmandu valley effect.

Generation and composition of $\mathrm{PM}_{10}$ and $\mathrm{PM}_{2.5}$ are decided by various source activities. The ratio of the mass concentration of $\mathrm{PM}_{10}$ and $\mathrm{PM}_{2.5}$ $\left(\mathrm{PM}_{2.5} / \mathrm{PM}_{10}\right)$ indicates the contribution from natural and anthropogenic sources (Querol et al. 2004). The low $\mathrm{PM}_{2.5} / \mathrm{PM}_{10}$ mass ratio infers to the dominance of primary or natural sources such as soil dust, sea salt, etc. (Chan and Yao 2008) whereas, the higher ratio shows more contribution from secondary particles originated from combustion activities (Perez et al. 2008). In the present study, pre-monsoon showed the lowest $\mathrm{PM}_{2.5} /$ $\mathrm{PM}_{10}$ ratio (0.54 in 2015 and 0.61 in 2016). This ratio in monsoon was 0.74 and 0.91 in 2015 and 2016 , respectively. In post-monsoon it was 0.75 and 0.92 in 2015 and 2016, respectively, whereas in winter it was 0.74 and 0.90 in 2016 and 2017, respectively. This confirms the major role of primary sources especially, dust particles. The coarse particles associated with the Asian dust storms have been reported to be the major pollutants in pre-monsoon (Wang et al. 2011). The average ratio of $\mathrm{PM}_{2.5} / \mathrm{PM}_{10}$ for 2015-2016 was 0.69 and that for 2016-2017 was 0.84 at Mahabaleshwar indicating the dominance of primary particle emissions by natural and man-made activities. The $\mathrm{PM}_{2.5} / \mathrm{PM}_{10}$ ratio was reported to be 0.37 at Lhasa, the capital of the Tibet Autonomous Region, located at a height of $3663 \mathrm{~m}$ in the centre of the Tibetan Plateau (Wang et al. 2015). At Darjeeling, a highaltitude location in Eastern Himalayan range the ratio was 0.66 (Chatterjee et al. 2010). Pipal and Satsangi (2015) have reported the $\mathrm{PM}_{2.5} / \mathrm{PM}_{10}$ ratio as 0.66 at Pune, an urban location near Mahabaleshwar. At Sinhagad (1450 m AMSL), another high-altitude site in the Western Ghat mountain range, the ratio was 0.67 (Satsangi et al. 2014). The ratio varied for different high-altitude stations due to variation in the concentration of 
Table 2. Mass concentration of $P M_{10}$ and $P M_{2.5}$ and $P M_{2.5} / P M_{10}$ ratios reported from different locations compared with the present study at Mahabaleshwar.

\begin{tabular}{|c|c|c|c|c|c|c|}
\hline No. & Site (type) & Altitude (m) & $\begin{array}{c}\mathrm{PM}_{10} \\
\left(\mu \mathrm{g} \mathrm{m}^{-3}\right)\end{array}$ & $\begin{array}{c}\mathrm{PM}_{2.5} \\
\left(\mu \mathrm{g} \mathrm{m}^{-3}\right)\end{array}$ & $\mathrm{PM}_{2.5} / \mathrm{PM}_{10}$ & References \\
\hline 1 & Lhasa, Tibet (high altitude) & 3663 & 37.7 & 14 & 0.37 & Wang et al. (2015) \\
\hline 2 & Sinhagad (high altitude) & 1450 & 35.8 & 14.1 & 0.39 & Satsangi et al. (2014) \\
\hline 3 & Darjeeling (high altitude) & 2200 & 29.5 & 19.6 & 0.66 & Chatterjee et al. (2010) \\
\hline 4 & Kathmandu, Nepal (high altitude) & 1400 & 169 & 69 & 0.41 & Putero et al. (2015) \\
\hline 5 & Pune (urban, metro) & 560 & 139 & 93 & 0.67 & Pipal and Satsangi (2015) \\
\hline 6 & Agra (urban) & 171 & 278 & 90 & 0.32 & Pipal et al. (2011) \\
\hline 7 & Mehboobnagar (semi-urban) & 450 & 69 & 50 & 0.72 & Bisht et al. (2015) \\
\hline 8 & Delhi (urban, metro) & 216 & 232 & 118 & 0.51 & Tiwari et al. (2015) \\
\hline 9 & Lucknow (urban) & 123 & 204 & 101 & 0.50 & Pandey et al. (2012) \\
\hline 10 & Patiala (urban) & 351 & 97 & 57 & 0.59 & Awasthi et al. (2011) \\
\hline 11 & Lahore (urban) & 351 & 489 & 91 & 0.19 & Colbeck et al. (2011) \\
\hline 12 & Beijing (urban, metro) & 44 & - & 86.6 & - & Zhao et al. (2009) \\
\hline 13 & Mahabaleshwar (high altitude) & 1348 & 37.79 & 26 & 0.69 & Leena et al. (2017) \\
\hline 14 & Mahabaleshwar (high altitude) & 1348 & 36.93 & 26.14 & 0.71 & Present study \\
\hline
\end{tabular}

PM. In this study the average $\mathrm{PM}_{2.5} / \mathrm{PM}_{10}$ ratio was comparable to or slightly higher than that reported at the above mentioned sites.

\subsection{Seasonal variation of PM}

Seasonal variation of aerosols is determined by changes in source activities, transport from distant sources and changes in meteorological patterns. The season-wise mean concentration of $\mathrm{PM}_{10}$ and $\mathrm{PM}_{2.5}$ for 2015 to 2016 is shown in figure 4. Analysis of PM data showed that in the year 2015-2016, the mean concentration of $\mathrm{PM}_{10}$ in pre-monsoon, monsoon, post-monsoon and winter was $73.5 \pm 14.8$, $15.6 \pm 5.1, \quad 51.6 \pm 4.0$ and $\quad 58.2 \pm 7.3 \mu \mathrm{g} \mathrm{m}^{-3}$, respectively, whereas that for $\mathrm{PM}_{2.5}$ in pre-monsoon, monsoon, post-monsoon and winter was $40.2 \pm 6.7$, $10.8 \pm 2.9, \quad 38.7 \pm 1.3$ and $43.4 \pm 4.5 \mu \mathrm{g} \mathrm{m}^{-3}$, respectively. Similarly, in 2016-2017, the mean concentration of $\mathrm{PM}_{10}$ in pre-monsoon, monsoon, postmonsoon and winter was $46.0 \pm 17.7,6.8 \pm 2.8$, $29.6 \pm 1.7$ and $33.5 \pm 1.8 \mu \mathrm{g} \mathrm{m}^{-3}$, respectively, whereas that for $\mathrm{PM}_{2.5}$ in pre-monsoon, monsoon, post-monsoon and winter was $29.2 \pm 8.2,5.8 \pm 2.1$, $27.2 \pm 1.3$ and $30.2 \pm 1.1 \mu \mathrm{g} \mathrm{m}{ }^{-3}$, respectively. For both the years, the order of observed mass concentration for $\mathrm{PM}_{10}$ was pre-monsoon $>$ winter $>$ postmonsoon $>$ monsoon, whereas that for $\mathrm{PM}_{2.5}$ was winter $>$ pre-monsoon $>$ post-monsoon $>$ monsoon. High loading of both $\mathrm{PM}_{10}$ and $\mathrm{PM}_{2.5}$ mass concentrations during the pre-monsoon season is due to the locally generated as well as long-range transported dust (Panicker et al. 2013; Tiwari et al. 2013), forest fires in nearby forests and an increase in the tourist related activities. The lower concentrations of $\mathrm{PM}_{10}$ and $\mathrm{PM}_{2.5}$ during the monsoon season are generally associated with the scavenging of aerosols through rain out and wash out processes due to the heavy precipitation received at this site $(>5000 \mathrm{~mm}$ seasonal mean). A study conducted in a high-altitude research station (5079 $\mathrm{m}$ AMSL) by Marinoni et al. (2010), recorded the highest aerosol concentrations during the pre-monsoon season that were associated with an increase in anthropogenic activities as well as dry weather conditions. The high concentration of $\mathrm{PM}_{2.5}$ in winter could be associated with prevailing meteorological conditions such as low WSs that restrict the dispersion of $\mathrm{PM}_{2.5}$ particles and low temperature which is not conducive to the diffusion of $\mathrm{PM}_{2.5}$ particles.

\subsection{Diurnal variation of $P M$}

Besides the daily, monthly and seasonal variability, $\mathrm{PM}_{10}$ and $\mathrm{PM}_{2.5}$ also exhibit pronounced diurnal variations which are attributed to the local emissions and prevailing meteorology (Dumka et al. 2015). The average hourly values of $\mathrm{PM}_{10}$ and $\mathrm{PM}_{2.5}$ concentrations (figure $5 \mathrm{a}$ and $\mathrm{b}$ ) show significant variations due to the variations in the planetary boundary layer (PBL). Atmospheric conditions also influence certain chemical reactions that lead to the formation of secondary aerosols. The morning peak is mainly attributed to the lifting up of particles due to the breakup of the nocturnal boundary layer by solar heating (Safai et al. 

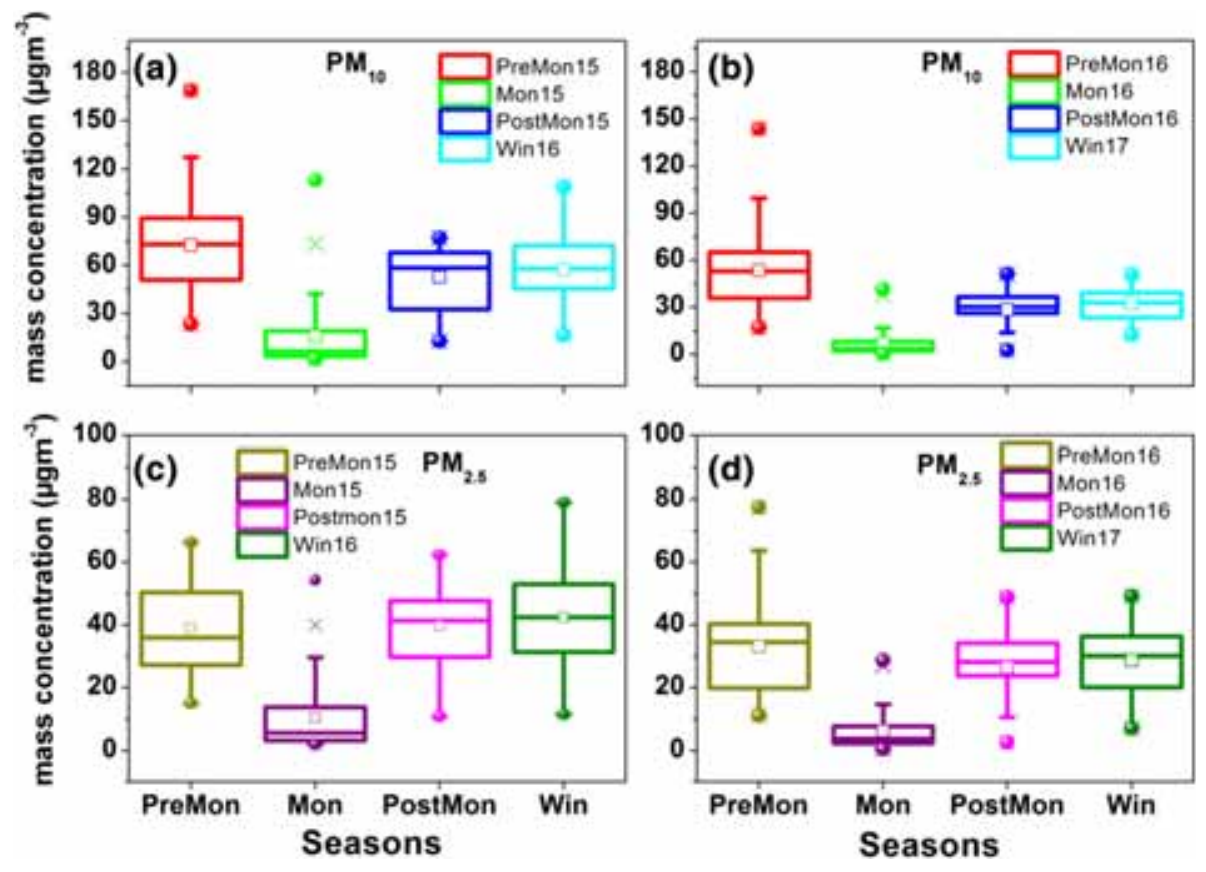

Figure 4. Box and Whisker plots showing seasonal variation of mass concentration of PM $_{10}$ during 2015-2016 (a), 2016-2017 (b) and that of $\mathrm{PM}_{2.5}$ during 2015-2016 (c) and 2016-2017 (d) over Mahabaleshwar (description: bottom and top of each box represent $25 \%$ and $75 \%$ quartile, respectively; line inside the box represents median values and small square represents mean, cross represents the outlier, bottom-filled circle represents minimum and upper-filled circle represents maximum values, respectively).

2007). The evening peak could be a combined effect of enhanced traffic emissions due to peak vehicular activity in the evening and the trapping of pollutants as a result of the temperature inversions and lowering of the boundary layer.

Figure 5(a) shows the hourly variation of $\mathrm{PM}_{10}$ during different seasons in 2015 and 2016. It is evident from this figure that the concentration of $\mathrm{PM}_{10}$ during the pre-monsoon gradually increased after sunrise $(6: 00 \mathrm{~h})$ and continued up to $16-17 \mathrm{~h}$ after which it decreased until succeeding morning. During monsoon, the $\mathrm{PM}_{10}$ concentration started to increase after sunrise and peaked at about 12:00 h followed by gradual decrease. During postmonsoon and winter, concentrations of $\mathrm{PM}_{10}$ increased gradually from about $06.00 \mathrm{~h}$ to peak at around 18-19 h before showing further decrease till next morning but with a small decrease in between 15 and $17 \mathrm{~h}$. However, during the winter season of 2016, the variation of $\mathrm{PM}_{10}$ was most uneven with many peaks and lows. Apart from variation in PBL, the effect of the mountain valley winds can influence the observed diurnal variation of $\mathrm{PM}_{10}$ in different seasons at Mahabaleshwar. Mountain and valley breezes are local winds caused by geographical feature of the area. During daytime, due to the warming of sun, the air along the mountain slopes raises up creating a valley breeze and carrying pollutants from valley to the mountain tops. During night hours, the air along the mountain slopes cools and moves down the mountain slopes into the valley, producing a mountain breeze and carrying pollutants from mountain top to the valley. Lang et al. (2015) and Bei et al. (2018) have reported an impact of mountain valley winds on transport of air pollutants. Interestingly at Mahabaleshwar, concentrations of $\mathrm{PM}_{10}$ throughout all the hours were significantly more in 2015 than those in 2016 during post-monsoon and winter. This could be related to higher rainfall in monsoon during 2016 (about $6735 \mathrm{~mm}$ seasonal total) than in 2015 (about $3776 \mathrm{~mm}$ seasonal total) which might have resulted in scavenging, especially more for coarse particles, i.e., $\mathrm{PM}_{10}$. The ratio values of mean $\mathrm{PM}_{10}$ concentration in pre-monsoon, monsoon, post-monsoon and winter in 2015 to those in 2016 were 1.4, 2.2, 1.8 and 1.8 , respectively. However, these ratio values for mean $\mathrm{PM}_{2.5}$ concentration were 1.2, 1.7, 1.5 and 1.5, respectively, in pre-monsoon, monsoon, post-monsoon and winter.

Hourly variation of $\mathrm{PM}_{2.5}$ (figure $5 \mathrm{~b}$ ) showed a continuous increase from $06.00 \mathrm{~h}$ with concentrations peaking around $17.00-18.00 \mathrm{~h}$ in 2015. A similar pattern was observed during 2016 except a peak at $09.00 \mathrm{~h}$ in morning. During monsoon, the concentration of $\mathrm{PM}_{2.5}$ showed an increase from 

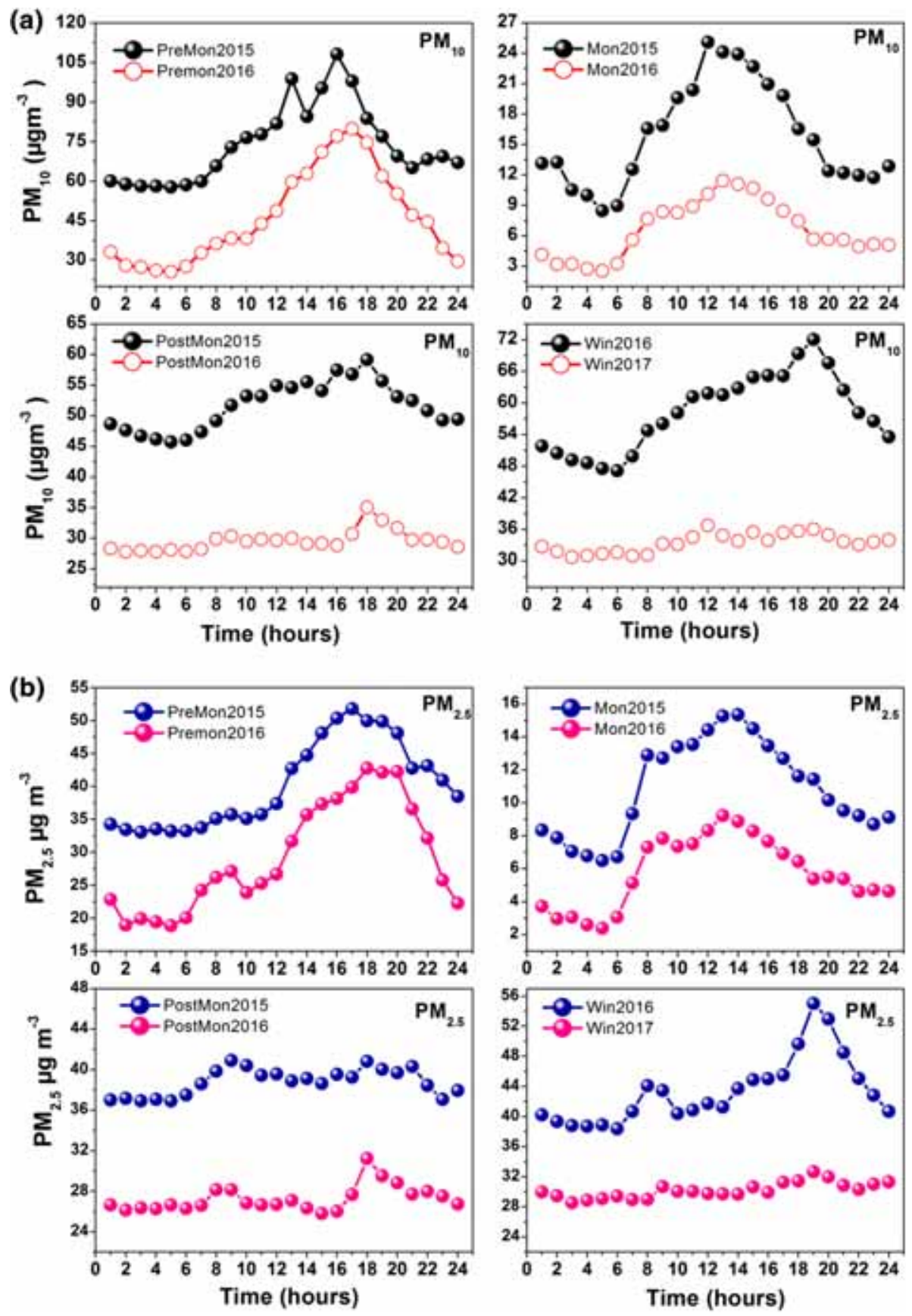

Figure 5. Mean diurnal variation of (a) $\mathrm{PM}_{10}$ and (b) $\mathrm{PM}_{2.5}$ concentrations during different seasons in 2015-2016 and 2016-2017 at Mahabaleshwar.

$06.00 \mathrm{~h}$ in morning which peaked at around 13.00-14.00 $\mathrm{h}$ followed by a gradual decrease in 2015 as well as in 2016. Post-monsoon and winter showed similar variation of $\mathrm{PM}_{2.5}$ exhibiting bimodal distribution with a morning (08.00-09.00 h) and evening (18.00-19.00 h) peak in 2015 and 2016. The morning and evening peaks coincide with enhanced anthropogenic activities at and near the site, mostly from certain combustion activities (burning of wood, dry leaves and cow dung cakes) for heating purposes in local surroundings (Nair et al. 2007). Stull (1988) suggested that the fumigation effect and evolution of the PBL height favour larger aerosol mass concentrations just after the sunrise, which when combined with the rush hour emission results in the higher loading during morning hours. As is observed in the case of $\mathrm{PM}_{10}$; the impact of more rainfall during 2016 compared to that in 2015 resulted in high concentration of $\mathrm{PM}_{2.5}$ across all the hours during post-monsoon and winter seasons in 2015. Changes in the diurnal pattern during 
different years in terms of occurrences of peaks and lows could be related to changes in PBL, mountain valley wind patterns as well as changes in the strength of emission sources in the local surroundings.

\subsection{Air mass back trajectory analysis}

Aerosols over a high-altitude site could be originated either from surrounding local sources or could be transported from other distant sources. At Mahabaleshwar, apart from the vehicular emissions especially from visiting tourist vehicles, certain agriculture related and domestic burning in the close surrounding contributed to the enhancement of PM. However, the possibility of long-range transport from other locations cannot be ruled out. Leena et al. (2017) have shown mixing heights reaching even up to $2400 \mathrm{~m}$ AGL at Mahabaleshwar. Mixing height depicts the extent of vertical transport from surface sources. Therefore, seven day air mass backward trajectories at a height of $3000 \mathrm{~m}$ above the ground level were studied using the HYSPLIT model. This model describes the information on the latitude, longitude and altitude of air mass pathways and is useful to identify the probable source regions (Lelieveld et al. 2002; Oanh et al. 2016; Ghim et al. 2017). Schauer et al. (2016) have reported the impact of long-range transport of Saharan dust along with emissions from wildfires over a high-altitude site in Austrian Alps. Figure 6 shows air mass backward trajectory analysis for each season at Mahabaleshwar during the study period. During the pre-monsoon season, air masses appeared to be travelling from the Arabian Peninsula as well as from the Thar Desert in the north western Indian region. In the monsoon season air mass was observed to be from the south west direction, i.e., from over the adjoining Arabian Sea indicating dominance of marine air masses. During post monsoon and winter, the air masses showed transport from the south eastern Indian region as well from the Arabian Peninsula which further passed through northern India. From the air mass back trajectory analysis it can be concluded that aerosols at Mahabaleshwar showed an influence on both marine and continental sources.

\subsection{Meteorological impact on PM}

In addition to the source emission rates, the prevailing meteorology in different seasons plays a key role in determining the fate of aerosols at any given location (Munir et al. 2017). Due to the temporal and spatial variation of the pollutant sources in different regions, the characteristics of $\mathrm{PM}$ observed in one region cannot be replicated to another region.

Generally, a higher WS is related to lower PM concentrations due to dispersal of particulates. Both $\mathrm{PM}_{2.5}$ and $\mathrm{PM}_{10}$ showed good anti-correlation with WS across all the seasons indicating dispersal of pollutants due to strong winds at Mahabaleshwar. This is inferred from the negative correlations between $\mathrm{PM}_{2.5}$ and WS during monsoon $(r=-0.52$, $p=0.002)$, post-monsoon $(r=-0.48, p=0.01)$ and winter $(r=-0.80, p<0.0001)$. Similarly, the negative correlation between $\mathrm{PM}_{10}$ and WS was observed during monsoon $(r=-0.51, p=0.004)$, post-monsoon $(r=-0.75, p=0.001)$ and winter $(r=-0.85, p=0.002)$. Interestingly, weak or insignificant anti-correlation between WS and both $\mathrm{PM}_{10}(r=-0.15, p=0.28)$ and $\mathrm{PM}_{2.5}(r=-0.12$, $p=0.45)$ was observed during pre-monsoon which can be attributed to the re-suspension of road dust or construction dust caused by enhanced tourist activity. In addition, dust particles carried away by winds from arid regions to the sampling location during this season could be the other reason. He et al. (2017) have reported relationship between PM and wind through regional transport at Beijing.

A strong positive correlation was found between atmospheric temperature and $\mathrm{PM}_{10}$ in pre-monsoon $(r=0.87, p<0.0001)$, monsoon $(r=0.90$, $p<0.0001)$, post-monsoon $(r=0.60, p=0.002)$ and winter $(r=0.69, p=0.001)$. Similarly, $\mathrm{PM}_{2.5}$ also showed good positive correlation with temperature in pre-monsoon $(r=0.45, p=0.002)$ and monsoon $(r=0.87, p<0.0001)$ and a comparatively less strong positive correlation in post monsoon $(r=0.25, p=0.03)$ and winter $(r=0.18$, $p=0.15)$. The effect of temperature on the formation of new particles through gas to particle conversion processes is reported by Jallad et al. (2013). High temperature promotes the photochemical reaction between precursor gases leading to particle formation (Wang and Ogawa 2015). RH was inversely correlated with $\mathrm{PM}_{10}(r=-0.71$, $p=0.001)$ and $\mathrm{PM}_{2.5} \quad(r=-0.60, p=0.006)$ during monsoon which is attributed to the wet deposition of aerosols. Abundance of atmospheric moisture $(\mathrm{RH}>80 \%)$ during the monsoon season might have helped fine suspended particles to bind together thereby forming heavier particles which eventually fall down. However, during pre- 

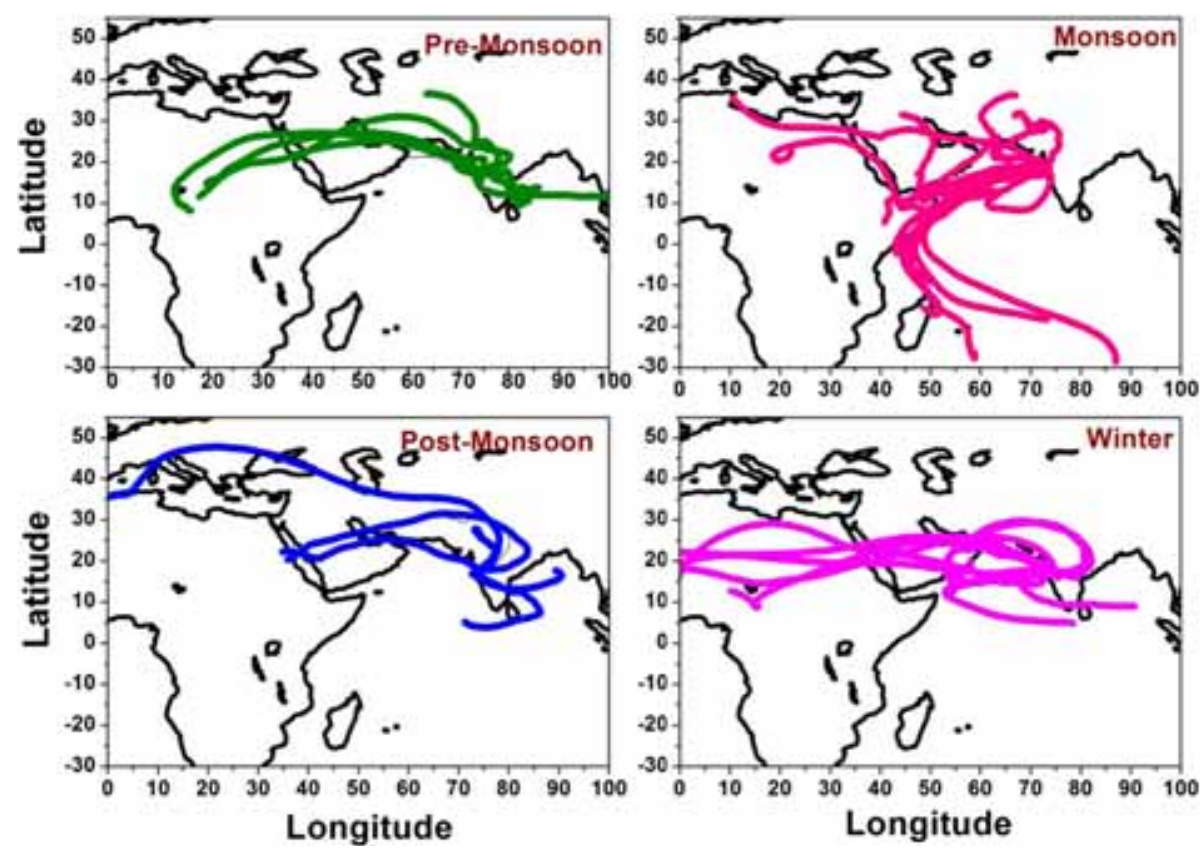

Figure 6. Season wise seven-day air mass backward trajectories at height of $3000 \mathrm{~m}$ during different seasons at Mahabaleshwar.

monsoon $(r=0.38, p=0.01)$ and post-monsoon $(r=0.35, p=0.08) \mathrm{PM}_{10}$ showed positive correlation with $\mathrm{RH}$ indicating moisture related hygroscopic growth of particles. Similarly $\mathrm{PM}_{2.5}$ also showed positive correlation with $\mathrm{RH}$ in pre-monsoon $(r=0.78, \quad p=0.002)$ and post-monsoon $(r=0.30, p=0.05)$. In contrast, $\mathrm{PM}_{10}(r=0.10$, $p=0.52)$ and $\mathrm{PM}_{2.5}(r=0.04, p=0.75)$ did not show a statistically significant correlation with $\mathrm{RH}$ during the winter season.

The correlation between $\mathrm{PM}_{10}$ and precipitation was negative $(r=-0.53$ and -0.95 in 2015 and 2016, respectively). During the monsoon season, rainfall is responsible for low $\mathrm{PM}_{10}$ and $\mathrm{PM}_{2.5}$ as they are washed out or scavenged by rain. More than $80 \%$ of rainfall over Mahabaleshwar occurs during the monsoon season, leading to strong wet removal of aerosols. The mean seasonal rainfall during monsoon over Mahabaleshwar is $>5000 \mathrm{~mm}$. Wet deposition by precipitation or wet removal is one of the main mechanisms for the removal of aerosols from the atmosphere (Jaenicke 1993). The monsoon season is characterised by heavy rain and strong winds both of which are conducive for the decrease in particulate pollutants.

\subsection{Exceedances of threshold limits for $P M_{10}$ and $P M_{2.5}$ levels}

The daily threshold limit set by the CPCB is $60 \mu \mathrm{g} \mathrm{m}^{-3}$ for $\mathrm{PM}_{10}$ and $40 \mu \mathrm{g} \mathrm{m}^{-3}$ for $\mathrm{PM}_{2.5}$
(CPCB 2009). At Mahabaleshwar, during 2015-2016, the CPCB threshold limit for $\mathrm{PM}_{10}$ was exceeded for 43, 04, 30 and 38 days, respectively in pre-monsoon, monsoon, post-monsoon and winter, whereas that for $\mathrm{PM}_{2.5}$ was exceeded for $31,02,28$ and 49 days, respectively, during the same seasons. Comparatively very fewer numbers of exceedances have been observed in 2016-2017. During 2016-2017, the CPCB threshold limit for $\mathrm{PM}_{10}$ was exceeded for 21 days in pre-monsoon with no exceedances during monsoon, post-monsoon and winter. Similarly, the CPCB threshold limit for $\mathrm{PM}_{2.5}$ was exceeded for 18,3 and 7 days in premonsoon, post-monsoon and winter, respectively, with no exceedances during monsoon (figure 7). Dust content in PM might be an important contributor to the enhanced levels of PM. A satellite and ground-based remote sensing technique is an invaluable tool in studying the long-term variation and transport of dust (Kaufman et al. 2005). Ghim et al. (2015) have investigated the influence of Asian dust on $\mathrm{PM}_{2.5}$ at Seoul. Based on the observations from 14 stations in Seoul, they have reported the occurrences of concentration spikes of $\mathrm{PM}_{2.5}$ levels in April and May 2002 when Asian dust storms were the strongest. Apart from the Asian dust effect, prevailing weather conditions were suggested to be conducive to fugitive dust generation during those months. $\mathrm{Pu}$ et al. (2015) observed enhancement in $\mathrm{PM}_{10}$ levels during spring over the Loess Plateau (1965 m AMSL) 

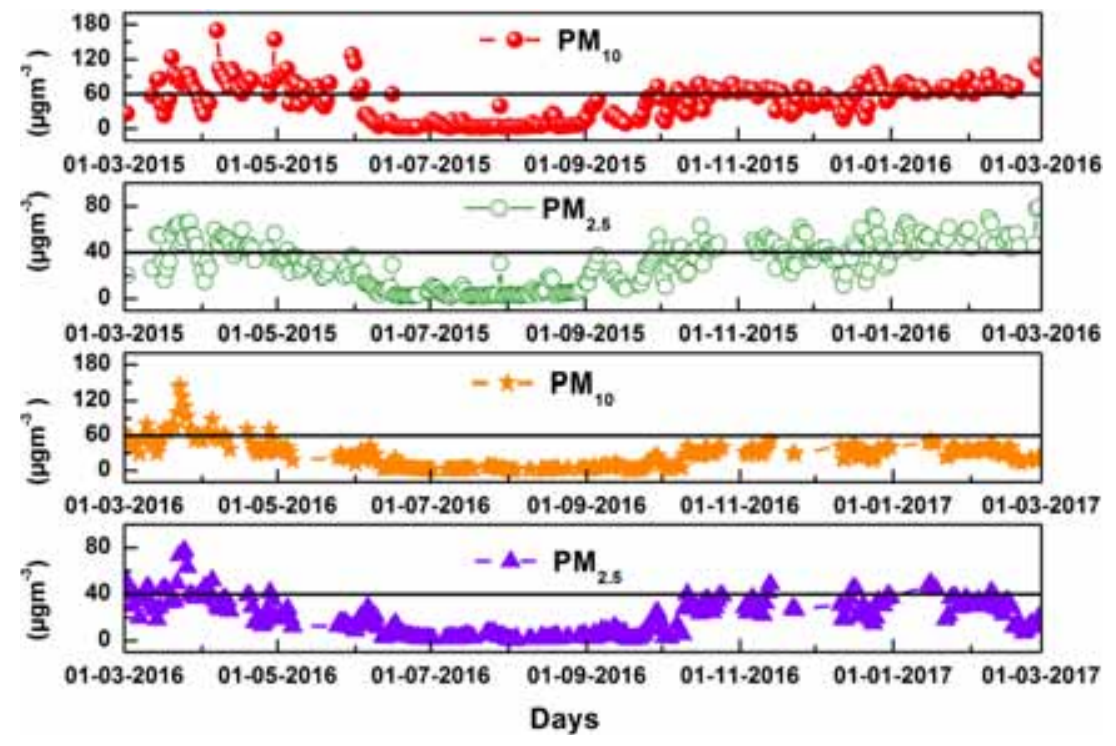

Figure 7. Number of exceedances of CPCB air quality standard values for $\mathrm{PM}_{10}$ and $\mathrm{PM}_{2.5}$ at Mahabaleshwar.

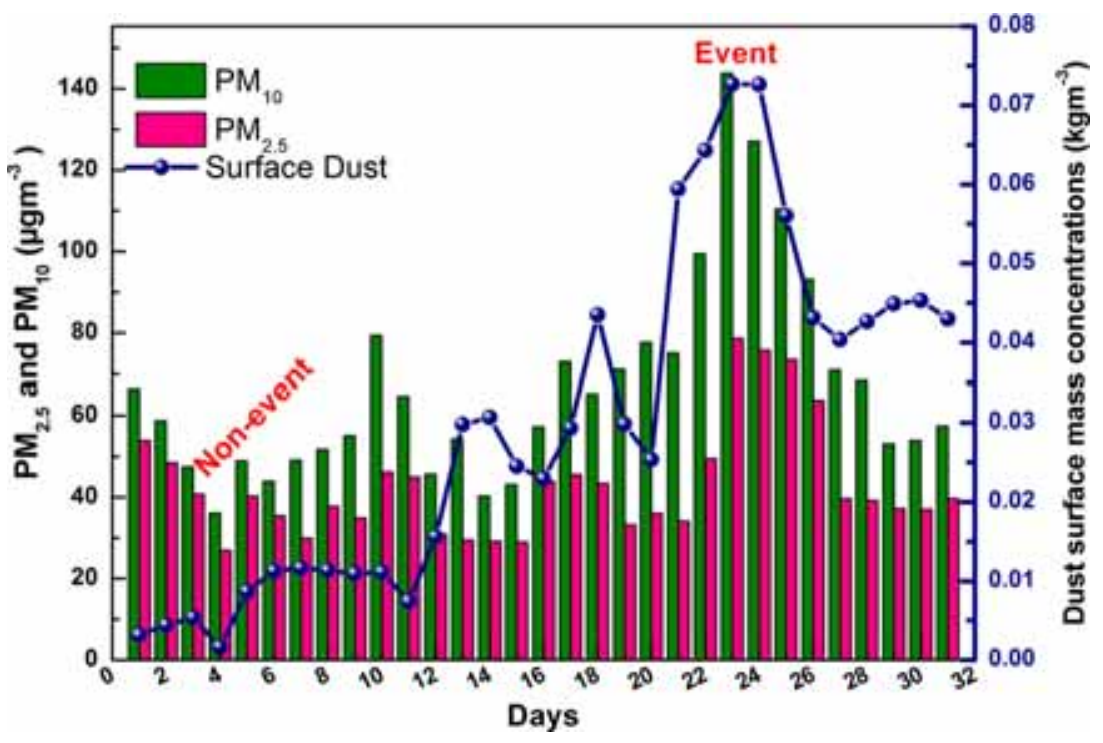

Figure 8. Daily variation of $\mathrm{PM}_{10}$ and $\mathrm{PM}_{2.5}$ and surface dust concentration obtained from satellite during 1 March to 31 March 2016 over Mahabaleshwar.

which was attributed to the frequent dust events. In India, dust storm events occur frequently over Thar and Margo Desert regions, and influence most parts of the north-north western India during premonsoon months from April to June (Pandithurai et al. 2008; Srivastava et al. 2011). The desert region of North Africa (forming about $65 \%$ of the global dust emissions) is the largest source of soil dust suspended in the atmosphere while Asian deserts are the second largest source (25\%). Strong dust storm events during pre-monsoon influence the aerosol number size distribution in the accumulation and coarse mode (Dey et al. 2004).
We have selected two typical cases representing the day with the highest $\mathrm{PM}_{10}$ concentration for 2015 and 2016. On 7th April 2015 the $\mathrm{PM}_{10}$ maximum concentration reached $443 \mu \mathrm{g} \mathrm{m}^{-3}$ and $\mathrm{PM}_{2.5}$ was $137 \mu \mathrm{g} \mathrm{m}^{-3}$. Similarly, on 23 March 2016 , the maximum concentration was 176.3 and $122.35 \mu \mathrm{g} \mathrm{m}{ }^{-3}$ for $\mathrm{PM}_{10}$ and $\mathrm{PM}_{2.5}$, respectively. Figure 8 shows the daily variation of PM from 1 March to 31 March 2016. It can be seen that PM values were significantly high on certain days. $\mathrm{PM}_{10}$ and $\mathrm{PM}_{2.5}$ ground observations over Mahabaleshwar were corroborated with the surface dust mass concentrations $\left(\mathrm{kg} \mathrm{m}^{-3}\right)$ for the month of 


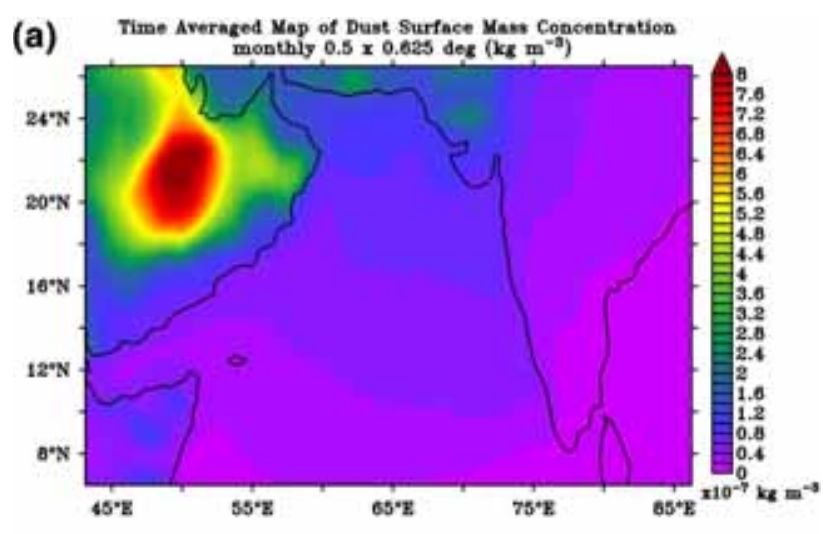

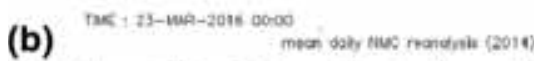

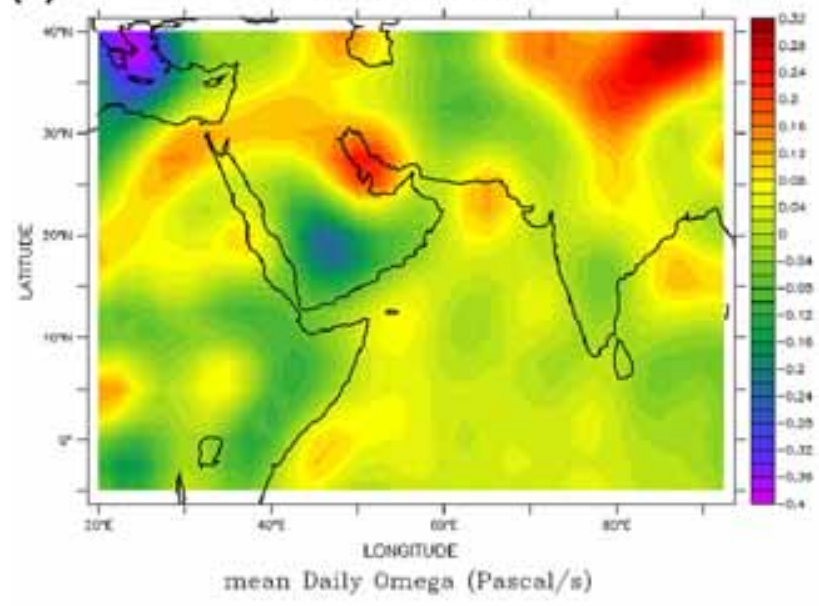

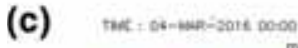

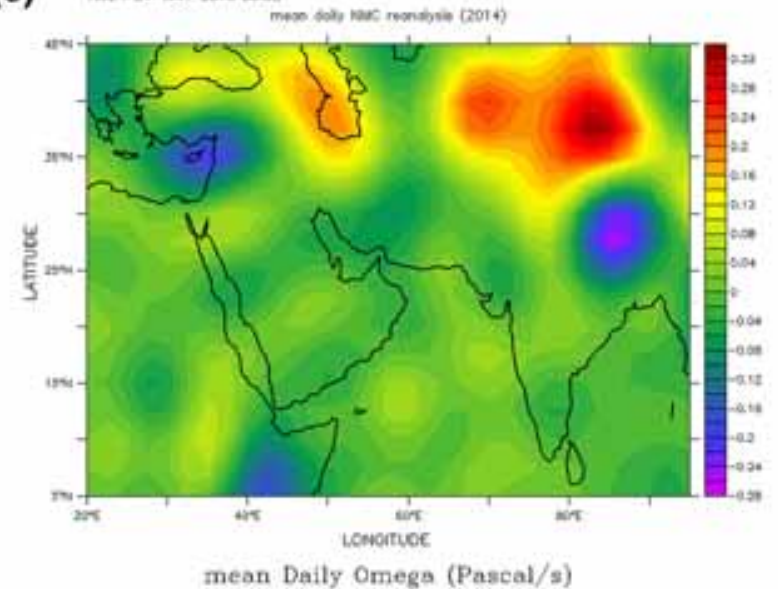

Figure 9. (a) Surface dust mass concentration in $\mathrm{kg} \mathrm{m}^{-3}$ for March 2016; (b) omega winds at the $1000 \mathrm{hPa}$ synoptic map for 00:00 UTC of 23 March 2016 (dust event) and (c) omega winds at the $1000 \mathrm{hPa}$ synoptic map for 00:00 UTC of $4 \mathrm{March}$ 2016 (non-dust event).

March 2016 (figure 9a) obtained from MERRA-2 which is the long term global reanalysis data set to assimilate satellite observations of aerosols representing their interactions with other physical processes in the climate system (https://giovanni.gsfc. nasa.gov/giovanni/, Earth Data, Giovanni,). The
MERRA-2 data matches thoroughly with the $\mathrm{PM}_{10}$ and $\mathrm{PM}_{2.5}$ ground observations over Mahabaleshwar. It can be seen that the dust surface mass concentration was very low in the first week of March, which gradually increased after 10th March and during 20 to 25 March the dust concentration attained the highest values $\left(0.07-0.08 \mathrm{~kg} \mathrm{~m}^{-3}\right)$. On 23 March, the highest concentration of $\mathrm{PM}_{10}$ and $\mathrm{PM}_{2.5}$ was recorded and it can be attributed to dust transported from distant sources.

\subsection{A case study for dust event and non-dust event days}

As stated above, two typical days have been selected on the basis of the mass concentration of $\mathrm{PM}_{10}$ and $\mathrm{PM}_{2.5}$ as event and non-event days. On 4 March 2016 the PM concentrations were found to be minimum in the month, therefore it is considered as non-event day, whereas, on 23 March the PM concentration was highest and is considered as an event day. Baltaci (2017) has shown the relationship between omega winds and the upward and downward movements of the dust particles. Using this method, the omega winds at the $1000 \mathrm{hPa}$ synoptic map were extracted for 00:00 coordinated universal time (UTC) of March 23. Figure 9(a) shows more dust mass generated over the source region, i.e., Arabian Peninsula during March 2016 and subsequently figure 9(b) and (c) show the mean daily omega wind values (https://www.esrl.noaa.gov/psd/data/gridded/data. ncep.reanalysis.pressure.html) for 23 March 2016 (dust event day) and 4 March 2016 (non-dust event day) which are indicative of the possible extent of downward transport of dust to the observational location. As shown in figure 9(b), sink regions (positive values) owing to the strong downward movements of air are shown indicating possible subsidence of the transported dust in this region leading to enhanced PM. It is quite clear from the spatial plots that there was a transport of dust to the study location on 23 March 2016. However, as seen from figure $9(\mathrm{c})$, the omega winds at the $1000 \mathrm{hPa}$ synoptic map extracted for 00.00 UTC of 4 March 2016 clearly indicated negative values inferring towards no sink regions indicating no transport of dust to the study location.

We have compared $\mathrm{PM}_{10}$ and $\mathrm{PM}_{2.5}$ mass concentration, chemical composition of non-refractory submicron aerosols $\left(\mathrm{NR} \mathrm{PM}_{1}\right)$, meteorological parameters and air mass back trajectories for both event (23 March 2016) and non-event (4 March 


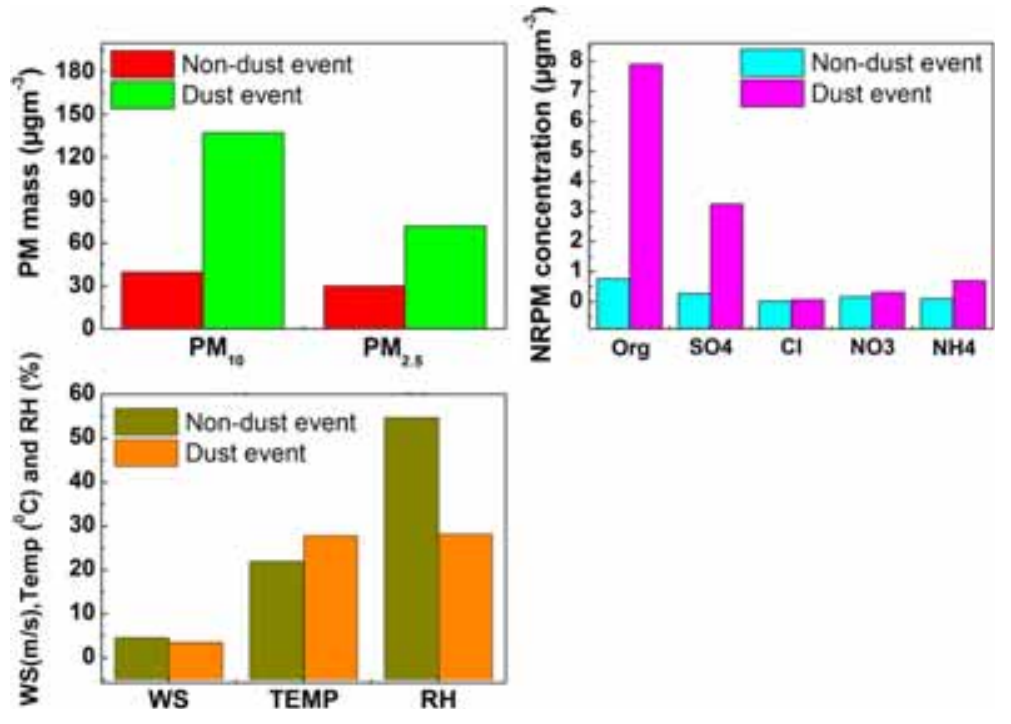

Figure 10. Variation of $\mathrm{PM}_{10}$ and $\mathrm{PM}_{2.5}$, meteorological parameters and chemical composition of $\mathrm{NR} \mathrm{PM}_{1}$ during non-dust event and dust event days at Mahabaleshwar.

2016) days. The $\mathrm{NR} \mathrm{PM}_{1}$ composition was obtained using ToF-ACSM which is described in section 2. Figure 10 shows the variation of various parameters during non-event and event days. The mass concentration of $\mathrm{PM}_{10}$ and $\mathrm{PM}_{2.5}$ was significantly higher during the event day as compared to the non-event day. The mean concentration of $\mathrm{PM}_{10}$ increased from $39.67 \mu \mathrm{g} \mathrm{m} \mathrm{m}^{-3}$ on the non-event day to $137.44 \mu \mathrm{g} \mathrm{\textrm {m } ^ { - 3 }}$ on the event day. Similarly, the mean concentration of $\mathrm{PM}_{2.5}$ increased from 29.90 to $71.94 \mu \mathrm{g} \mathrm{m}^{-3}$. Zhao et al. (2011) reported a significant increase in $\mathrm{PM}_{10}$ and $\mathrm{PM}_{2.5}$ during dust episodes at the coastal city of Xiamen in China. Among the meteorological parameters, ambient temperature ranged from 23 to $31^{\circ} \mathrm{C}$ on the event day, whereas on the non-event day, it ranged from 21 to $22^{\circ} \mathrm{C}$. The WS was relatively low (1.3 to $1.9 \mathrm{~m} \mathrm{~s}^{-1}$ ) on the event day. However on the non-event day the WS varied between 4.3 and $7.4 \mathrm{~m} \mathrm{~s}^{-1}$. RH was lower on the event day ranging from $15 \%$ to $50 \%$, whereas it was $46 \%$ to $60 \%$ on the non-event day. Since RH was low during dust episodes, it is assumed that the heterogeneous reactions of $\mathrm{SO}_{2}$ on dust particles could have led to the formation of $\mathrm{SO}_{4}{ }^{2-}$ (Yang et al. 2016).

Concentrations of all the observed $\mathrm{NR} \mathrm{PM}_{1}$ components showed higher values on the event day, especially more for organics and sulphate. The mean concentration of organics on the non-event day was 0.76 and $7.9 \mu \mathrm{g} \mathrm{m}^{-3}$ on the event day. Similarly, the mean concentration of sulphate was $0.27 \mu \mathrm{g} \mathrm{m}^{-3}$ on the non-event day and $3.25 \mu \mathrm{g} \mathrm{m}$ on the event day. The main formation pathways of nitrate and sulphate during the dust process are photo-oxidation of $\mathrm{NO}_{2}$ and $\mathrm{SO}_{2}$, respectively via $\mathrm{OH}$ radicals (Wang et al. 2014). The average $\mathrm{PM}_{2.5} / \mathrm{PM}_{10}$ ratio on the event day was 0.54 and that on the non-event day was 0.69 indicating more coarse-sized dust particles during the dust storm episode. Dust transport from the Arabian Peninsula is one of the important sources which contributed significantly to the PM mass on the dust event day.

As seen from figure 11(a), the air mass back trajectories on an event day 23 March 2016 at 1500, 2500 and 3000 AMSL seem to be coming from the north western region inferring to the impact of long-range transport of dust from the Arabian Peninsula. This is further evident from figure 11(b) which shows a spatial plot of U and V winds over the Indian region on the event day at $850 \mathrm{hPa}$, showing a cyclonic circulation in the study region and winds approaching from the western dry region (NCEP Reanalysis data at http://www.esrl.noaa.gov/psd/).

Figure 11(c) shows the air mass trajectories for 4 March 2016 (non-event day) at 1500, 2500 and 3000 AMSL. It can be seen that at all the altitudes, the winds are coming from Bay of Bengal passing over the Southern Indian region and then partly over the Arabian Sea before reaching the site. Also, the NCEP spatial plot of $U$ and $V$ winds over the Indian region on 4 March 2016 (non-event day) at $850 \mathrm{hPa}$ (figure 11d) showed majority of the winds from the east-south eastern region. 


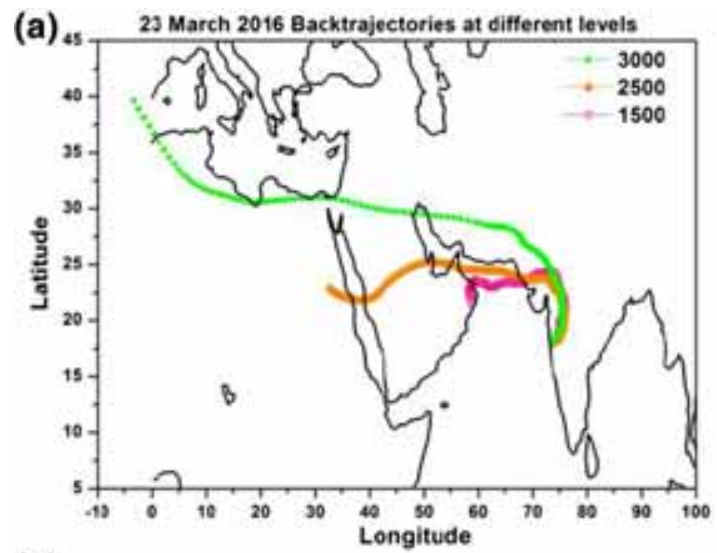

(b)

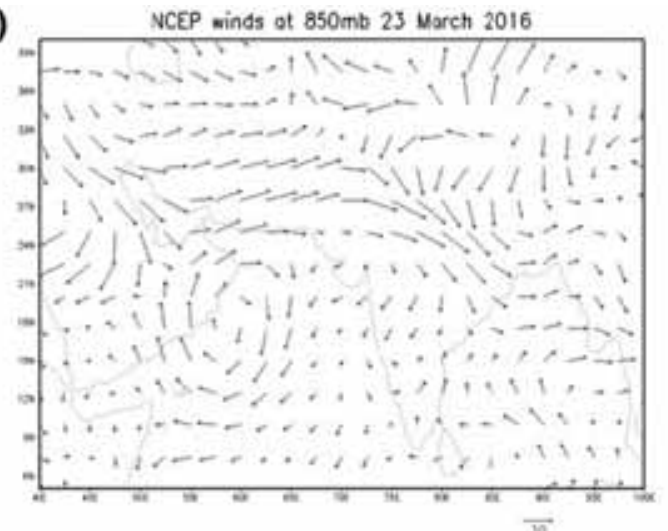

(c)

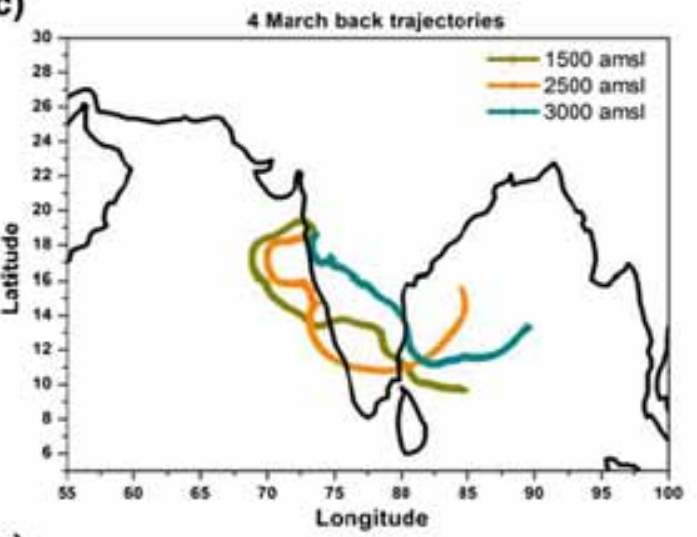

(d)

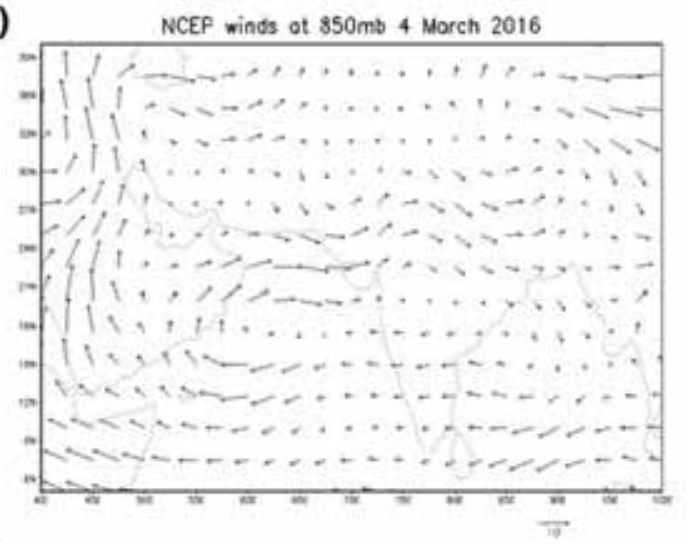

(e)

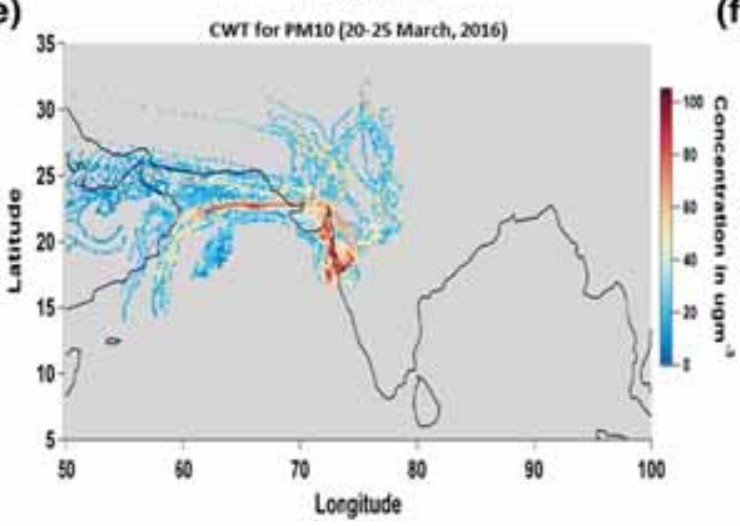

(f)

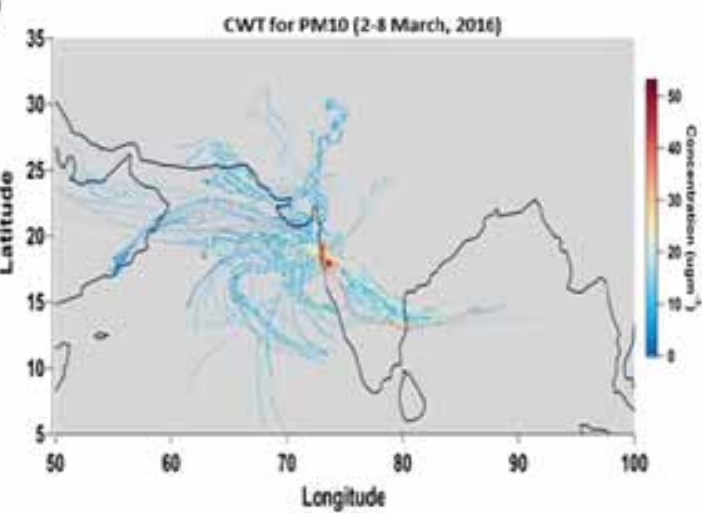

Figure 11. (a) and (c) show the back trajectories on dust event and non-dust event days at three different altitudes, (b) and (d) show the spatial plot of $\mathrm{U}$ and $\mathrm{V}$ winds over the Indian region on an event and non-event days at $850 \mathrm{hPa}$ at Mahabaleshwar. (e) CWT for $\mathrm{PM}_{10}$ during the event days (20-25 March, 2016) and (f) CWT for $\mathrm{PM}_{10}$ during non-dust event days (2-8 March, 2016).

To describe the role of transport from other regions, we have performed CWT analysis (Petit et al. 2017) on $\mathrm{PM}_{2.5}$ and $\mathrm{PM}_{10}$ data during the event (20-25 March, 2016) and non-event (2-8 March, 2016) periods. It can be seen from figure 11(e) that during the dust event days, the high concentration of PM is mostly contributed from (i) Gujarat and Thar Desert, (ii) Mumbai Metro City and (ii) African gulf region. The analysis provides evidence for episodes showing an impact of transported dust on observed high concentration of PM. In addition to the long-range dust transport, the possible regional transport from surrounding regions like Gujarat and Mumbai might have contributed significantly to the organics and sulphate mass loading as evident from CWT analysis for event and non-event days. The incursion of certain low-volatile organic vapours and sulphuric acid/sulphur dioxide from these industrial regions could have found more heterogeneous aerosol surface (heterogeneous aerosol processing) to be deposited onto it during dust event days as compared to non-event days. This might have led to the observed higher loading of 
organics and sulphate during event days. In contrast to dust event days, the CWT analysis during the non-event days (figure 11f) showed that the PM is mostly contributed by the transport from the Arabian Sea and South Eastern Indian region apart from little contribution from the Mumbai region.

Overall, the current assessment of the fine and coarse particles over Mahabaleshwar will strengthen our understanding about the influence of local sources, long-range transport and local meteorological conditions on the PM over this high-altitude site.

\section{Conclusions}

Levels of $\mathrm{PM}_{10}$ and $\mathrm{PM}_{2.5}$ were monitored during March 2015 to February 2017 at Mahabaleshwar, a high-altitude station. The mean concentration of $\mathrm{PM}_{2.5}$ was maximum in winter followed by premonsoon whereas that for $\mathrm{PM}_{10}$ was maximum in pre-monsoon followed by winter. The lowest concentrations for both were observed in monsoon. The winter season experiences more combustion activities in the local surrounding as well as low ventilation of fine particulates due to low-mixing heights thereby showing enhancement in $\mathrm{PM}_{2.5}$. The high $\mathrm{PM}_{10}$ concentration in the pre-monsoon season was attributed to the long-range transport of dust from the Arabian peninsula, more vehicular emissions due to peak tourist activity and prevailing boundary layer conditions. Scavenging of aerosols due to heavy rains at this site resulted in minimum concentrations during the monsoon. The concentrations of $\mathrm{PM}_{2.5}$ and $\mathrm{PM}_{10}$ were higher in all the seasons in 2015 as compared to 2016 which could be related to comparatively higher rainfall in 2016. The diurnal variation of $\mathrm{PM}_{2.5}$ and $\mathrm{PM}_{10}$ could be attributed to changes in PBL, mountain valley wind patterns as well as changes in the strength of emission sources in the local surroundings. The ratio of $\mathrm{PM}_{2.5} / \mathrm{PM}_{10}$ suggests the dominance of $\mathrm{PM}_{10}$ inferring towards more contribution of coarse particles. During the pre-monsoon season, the concentrations of both $\mathrm{PM}_{2.5}$ and $\mathrm{PM}_{10}$ exceeded the threshold limit set by $\mathrm{CPCB}$ on many occasions which could be attributed to the long-range transport of dust from the Arabian peninsula during dust storm episodes. Chemical species, especially organics and sulphate showed enhancement during dust episodes. Air mass back trajectories and CWT analysis for dust event and non-event days indicated the possible long-range transport of aerosols over the site. The results of the present study inferred to the impact of both local and transported aerosols over a high-altitude location, Mahabaleshwar during the study period.

The present study may have significant climatic implications for this topographically and ecologically very sensitive region over the Western Ghats. The presence of desert dust particles in the atmosphere might play a key role in the energy distribution and the formation of the regional climate over this high-altitude site.

\section{Acknowledgements}

The authors are thankful to the Director of IITM for his support and encouragement. High Altitude Cloud Physics Laboratory (HACPL), part of IITM is fully funded by Ministry of Earth Sciences (MoES), Government of India. The authors are grateful to all the team members of HACPL, IITM. The data used in this study are from the data repository of HACPL.

\section{References}

ACES (Department of Environmental Science and Analytical Chemistry), Atmospheric Science Unit, Stockholm University 2012 Equivalence of PM10 instruments at a road traffic site: a study in Stockholm spring 2012, ACES report 4, complied by Areskoug, Hans.

Allan J D, Delia A E, Coe H, Bower K N, Alfarra M, Jimenez J L, Middlebrook A M, Drewnick F, Onasch T B, Canagaratna M R, Jayne J T and Worsnop D R 2004 A generalised method for the extraction of chemically resolved mass spectra from Aerodyne aerosol mass spectrometer data; J. Aerosol Sci. 35 909-922.

Al Jallad F, Al Katheeri E and Al Omar M 2013 Concentrations of particulate matter and their relationships with meteorological variables; Sustain. Environ. Res. 23(3) 191-198.

Awasthi A R, Agarwal S K, Mittal N, Singh K and Gupta P K 2011 Study of size and mass distribution of particulate matter due to crop residue burning with seasonal variation in rural area of Punjab, India; J. Environ. Monit. 13 1073-1081.

Baltaci H 2017 Spatial and temporal variation of the extreme Saharan dust event over Turkey in march 2016; Atmosphere (Basel) 841.

Bei N, Zhao L, Wu J, Li X, Feng T and Li G 2018 Impacts of sea-land and mountain-valley circulations on the air pollution in Beijing-Tianjin-Hebei (BTH): A case study; Environ. Pollut. 234 429-438.

Bisht D S, Srivastava A K, Pipal A S, Srivastava M K, Pandey A K, Tiwari S and Pandithurai G 2015 Aerosol characteristics at a rural station in southern peninsular India during 
CAIPEEX-IGOC: Physical and chemical properties; Environ. Sci. Pollut. Res. 22 5293-5304.

Burnett R, Pope A, Ezzati M, Olives C, Lim S, Mehta S, Shin H, Singh G, Hubbell B, Brauer M, Anderson H, Smith K, Balmes J, Bruce N, Kan H, Laden F, PrüsseUstün A, Turner M, Gapstur S, Diver W and Cohen A 2014 An integrated risk function for estimating the global burden of disease attributable to ambient fine particulate matter exposure; Environ. Health Perspect. 122(4) 307-404.

Carrico C M, Bergin H M, Shrestha A B, Dibb J E and Gomes L 2003 The importance of carbon and mineral dust to seasonal aerosol properties in the Nepal Himalayas; Atmos. Environ. (UK) 37 2811-2824.

CPCB (Central Pollution Control Board), Government of India 2009 Nationalambient air quality standards notification.

Chan C K and Yao X 2008 Air pollution in mega cities in China; Atmos. Environ. 42 1-42.

Chatterjee A, Adak A, Singh A K, Srivastava M K, Ghosh S K and Tiwari S 2010 Aerosol chemistry over a high altitude station at north-eastern Himalayas, India; PLoS ONE 5(6) e11122, https://doi.org/10.1371/journal.pone.0011122.

Colbeck I, Nasir Z A, Ahmad S and Ali Z I 2011 Exposure to PM10, PM2.5, PM1 and carbon monoxide on roads in Lahore, Pakistan; Aerosol Air Qual. Res. 11 689-695.

Dey S, Tripathi S N, Singh R P and Holben B N 2004 Influence of dust storms on the aerosol optical properties over the Indo-Gangetic basin; J. Geophys. Res. 109 D20211.

Draxler R R and Rolph G D 2003 HYSPLIT (Hybrid Singleparticle Lagrangian Integrated Trajectory) Model Access via NOAA ARL READY NOAA Air Resources Laboratory, Silver Spring, MD, http://ready.arl.noaa.gov/ HYSPLIT.php.

Du Y, Xu X, Chu M, Guo Y and Wang J 2016 Air particulate matter and cardiovascular disease: The epidemiological, biomedical and clinical evidence; J. Thorac. Dis. 8(1) 8-19.

Dumka U C, Kaskaoutis D G, Srivastava M K and Devara P C S 2015 Scattering and absorption properties of near-surface aerosol over Gangetic-Himalayan region: The role of boundary-layer dynamics and long-range transport; Atmos. Chem. Phys. 15 1555-1572.

Frohlich R, Cubison M J, Slowik J G, Bukowiecki N, Prevot A S H, Baltensperger U and Jayne J T 2013 The ToF-ACSM: A portable aerosol chemical speciation monitor with TOFMS detection; Atmos. Meas. Tech. 6 3225-3241.

Gawhane R D, Rao P S P, Budhavant K B, Waghmare V, Meshram D C and Safai P D 2017 Seasonal variation of chemical composition and source apportionment of PM2.5 in Pune, India; Environ. Sci. Pollut. Res. 24 2106521072.

Ghim Y S, Chang Y and Kim J Y 2015 Temporal and spatial variations in fine and coarse particles in Seoul, Korea; Aerosol Air Qual. Res. 15 842-852.

Ghim Y S, Kim J Y and Chang Y 2017 Concentration variations in particulate matter in Seoul associated with Asian dust and smog episodes; Aerosol Air Qual. Res. 17 3128-3140.

He J, Mao H, Gong S, Yu Y, Wu L, Liu H, Chen Y, Jing B, Ren P and Zou C 2017 Investigation of particulate matter regional transport in Beijing based on numerical simulation; Aerosol Air Qual. Res. 17 1181-1189.
Jaenicke R 1993 Tropospheric aerosols; In: Aerosol-Cloud-Climate Interactions (ed.) Hobbs P, Academic Press, SanDiego, CA, pp. 1-31.

Kaufman Y J, Koren I, Remer L A, Tanre D, Ginoux P and Fan S 2005 Dust transport and deposition observed from the terra-moderate resolution imaging spectro radiometer (MODIS) spacecraft over the Atlantic Ocean; J. Geophys. Res. 11010.

Khemani L T 1989 Physical and Chemical Characteristics of Atmospheric Aerosols. Air Pollution Control; Encyclopedia of Environmental Control Technology, 2; Gulf Publ. Co., USA, pp. 401-452.

Lang M N, Gohm A and Wagner JS 2015 The impact of embedded valleys on daytime pollution transport over a mountain range; Atmos. Chem. Phys. 15 11981-11998.

Leena P P, Vijayakumar K, Anilkumar V and Pandithurai G 2017 Analysing temporal variability of particulate matter and possible contributing factors over Mahabaleshwar, a high-altitude station in Western Ghats, India; J. Atmos. Sol.-Terr. Phys. 164 105-115.

Lelieveld J, Berresheim H, Borrmann S, Crutzen P J, Dentener F J, Fischer H, Feichter J, Flatau P J, Heland J, Holzinger R, Korrmann R, Lawrence M G, Levin Z, Markowicz K M, Mihalopoulos N, Minikin A, Ramanathan V, de Reus M, Roelofs G J, Scheeren H A, Sciare J, Schlager H, Schultz M, Siegmund P, Steil B, Stephanou E G, Stier P, Traub M, Warneke C, Williams J and Ziereis H 2002 Global air pollution crossroads over the Mediterranean; Science 298 794-799.

Marinoni A, Cristofanelli P, Laj P, Duchi R, Calzolari F, Decesari S and Bonasoni P 2010 Aerosol mass and black carbon concentrations, a two year record at NCO-P (5079 m, Southern Himalayas); Atmos. Chem. Phys. 10(17) 8551-8562.

Munir S, Habeebullah T M, Mohammed Atef M F, Morsy E A, Rehan M and Ali K 2017 Analysing PM2.5 and its association with PM10 and meteorology in the arid climate of Makkah, Saudi Arabia; Aerosol Air Qual. Res. 17 453-464.

Nair V S, Moorthy K K, Alappattu D P, Kunhikrishnan P K, George S, Nair P R, Babu S S, Abish B, Satheesh S K, Tripathi S N, Niranjan K, Madhavan B L, Srikant V, Dutt C B S, Badarinath K V S, Reddy R R 2007 Wintertime aerosol characteristics over the Indo-Gangetic Plain (IGP): Impacts of the local boundary layer processes and longrange transport; J. Geophys. Res. 112 D13205.

Ng N L, Herndon S C, Trimborn A, Canagaratna M R, Croteau P L, Onasch T B, Sueper D, Worsnop D R, Zhang Q, Sun Y L and Jayne J T 2011 An aerosol chemical speciation monitor (ACSM) for routine monitoring of the composition and mass concentrations of ambient aerosol; Aerosol Sci. Technol. 45 780-794.

Oanh N T K, Nguyen Hang T, Aungsiri T, Worrarat T and Danutawat T 2016 Characterization of particulate matter measured at remote forest site in relation to local and distant contributing sources; Aerosol Air Qual. Res. 16 2671-2684.

Pandey P, Khan A H, Verma A K, Singh K A, Mathur N, Kisku G C and Barman S C 2012 Seasonal trends of PM2.5 and PM10 in ambient air and their correlation in ambient air of Lucknow city, India; Bull. Environ. Contam. Toxicol. 88265. 
Pandithurai G, Dipu S, Dani K K, Tiwari S, Bisht D S, Devara P C S and Pinker R T 2008 Aerosol radiative forcing during dust events over New Delhi, India; J. Geophys. Res.. https://doi.org/10.1029/2008JD009804.

Panicker A S, Lee D I, Kumkar Y V, Kim D, Maki M and Uyeda H 2013 Decadal climatological trends of aerosol optical parameters over three different environments in South Korea; Int. J. Climatol. 33 81909-81916.

Panicker A S, Ali K, Beig G and Yadav S 2015 Characterization of particulate matter and carbonaceous aerosol over two urban environments in Northern India; Aerosol Air Qual. Res. 15(7) 2584-2595.

Perez N, Pey J, Querol X, Alastuey A, Lopez J M and Viana M 2008 Partitioning of major and trace components in $\mathrm{PM}_{10}-\mathrm{PM}_{2.5}-\mathrm{PM}_{1}$ at an urban site in Southern Europe; Atmos. Environ. 42 1677-1691.

Petit J E, Favez O, Albinet A and Canonaco F 2017 A userfriendly tool for comprehensive evaluation of the geographical origins of atmospheric pollution: Wind and trajectory analyses; Environ. Model. Softw. 88 183-187.

Pipal A S and Satsangi P G 2015 Study of carbonaceous species, morphology and sources of fine $\left(\mathrm{PM}_{2.5}\right)$ and coarse $\left(\mathrm{PM}_{10}\right)$ particles along with their climatic nature in India; Atmos. Res. 154 103-115.

Pipal A S, Kulshrestha A and Taneja A 2011 Characterization and morphological analysis of airborne $\mathrm{PM}_{2.5}$ and $\mathrm{PM}_{10}$ in Agra located in north central India; Atmos. Environ. 21 3621-3630.

Pu W, Wang X, Zhang X, Ren Y, Shi J-S, Bi J-R and Zhang B-D 2015 Size distribution and optical properties of particulate matter $\left(\mathrm{PM}_{10}\right)$ and black carbon $(\mathrm{BC})$ during dust storms and local air pollution events across a Loess Plateau site; Aerosol Air Qual. Res. 15 2212-2224.

Putero D, Cristofanelli P, Marinoni A, Adhikary B, Duchi R and Shrestha S D 2015 Seasonal variation of ozone and black carbon observed at Paknajol, an urban site in the Kathmandu Valley, Nepal; Atmos. Chem. Phys. 15(24) 13957-13971.

Querol X, Alastuey A and Rodriguez S 2004 Levels of particulate matter in rural, urban and industrial sites in Spain; Sci. Total Environ. 334-345 359-376.

Rengarajan R, Sudheer A K and Sarin M M 2011 Wintertime PM2.5 and PM10 carbonaceous and inorganic constituents from urban site in western India; Atmos. Res. 102(4) 420-431.

Safai P D, Rao P S P, Momin G A, Ali K, Chate D M, Praveen P S and Devara P C S 2005 Variation in the chemistry of aerosols in two different winter seasons at Pune and Sinhagad, India; Aerosol Air Qual. Res. 5(1) 115-126.

Safai P D, Kewat S, Praveen P S, Rao P S P, Momin GA, Ali K and Devara P C S 2007 Seasonal variation of black carbon aerosols over a tropical urban city of Pune, India; Atmos. Environ. 41 2699-2709.

Safai P D, Budhavant K B, Rao P S P, Ali K and Sinha A 2010 Source characterization for aerosol constituents and changing roles of calcium and ammonium aerosols in the neutralization of aerosol acidity at a semi-urban site in SW India; Atmos. Res. 98 78-88.

Satsangi P G, Chavan S P, Rao P S P and Safai P D 2014 Chemical characterization of particulate matter at Sinhagad, a high altitude station in Pune, India; Indian J. Radio Space Phys. 43 284-292.
Schauer G, Kasper-Giebl A and Mocnik G 2016 Increased PM concentrations during a combined wildfire and Saharan dust event observed at high-altitude sonnblick observatory, Austria; Aerosol Air Qual. Res. 16(3) 542-554.

Singla V, Mukherjee S, Safai P D, Meena G S, Dani K K and Pandithurai G 2017 Role of organic aerosols in CCN activation and closure over a rural background site in Western Ghats, India; Atmos. Environ. 158 148-159.

Song Q, Christiani D, Wang X and Ren J 2014 The global contribution of outdoor air pollution to the incidence, prevalence, mortality and hospital admission for chronic obstructive pulmonary disease: A systematic review and meta-analysis; Int. J. Environ. Res. Public Health 11(11) $11822-11832$.

Sreekanth V, Mahesh B and Niranjan K 2018 Gradients in $\mathrm{PM}_{2.5}$ over India: Five city study; Urban Clim. 25 99-108.

Srivastava A K, Pant P, Hegde P, Singh S, Dumka U C, Naja M, Singh N and Bhavanikumar Y 2011 Influence of South Asian dust storm on aerosol radiative forcing at a highaltitude station in central Himalayas; Int. J. Remote Sens. 32(22) $7827-7845$.

Stull R B 1988 An Introduction to Boundary Layer Meteorology; Kluwer Academic, Dordrecht, pp. 115-149.

Tiwari S, Chate D M, Srivastava M K, Safai P D, Srivastava A K, Bisht D S and Padmanabhamurty B 2012 Statistical evaluation of PM10 and distribution of $\mathrm{PM}_{1}, \mathrm{PM}_{2.5}$, and $\mathrm{PM}_{10}$ in ambient air due to extreme fireworks episodes (Diwali festivals) in megacity Delhi; Nat. Hazard 61(2) 521-531.

Tiwari S, Srivastava A K, Bisht D, Parmita P, Srivastava M K and Attri S 2013 Diurnal and seasonal variations of black carbon and PM 2.5 over New Delhi, India: Influence of meteorology; Atmos. Res. 125 50-62.

Tiwari S, Hopke P K, Pipal A S, Srivastava A K, Bisht D S, Tiwari S, Singh A K, Soni V K and Attri S D 2015 Intraurban variability of particulate matter (PM2.5 and PM10) and its relationship with optical properties of aerosols over Delhi, India; Atmos. Res. 166 223-232.

van Donkelaar A, Martin R V, Brauer M, Kahn R, Levy R, Verduzco C and Villeneuve P J 2010 Global estimates of ambient fine particulate matter concentrations from satellite-based aerosol optical depth: Development and application; Environ. Health Perspect. 118 847-855.

Wang J and Ogawa S 2015 Effects of meteorological conditions on $\mathrm{PM}_{2.5}$ concentrations in Nagasaki, Japan; Int. J. Environ. Res. Public Health 12 9089-9101.

Wang S H, Tsay S C, Lin N H, Hsu N C, Bell S W, Li C, Ji Q, Jeong M J, Hansell R A, Welton E J, Holben B N, Sheu G R, Chu Y C, Chang S C, Liu J J and Chiang W L 2011 First detailed observations of long-range transported dust over the Northern South China Sea; Atmos. Environ. 45 4804-4808.

Wang Y Q, Zhang X Y, Sun J Y, Zhang X C, Che H Z and Li Y 2015 Spatial and temporal variations of the concentrations of $\mathrm{PM}_{10}, \mathrm{PM}_{2.5}$ and $\mathrm{PM}_{1}$ in China; Atmos. Chem. Phys. 15 13585-13598.

Wang Y, Zhang Q, Jiang J, Zhou W, Wang B, He K, Duan F, Zhang Q, Philip S and Xie Y 2014 Enhanced sulfate formation during China's severe winter haze episode in January 2013 missing from current models; J. Geophys. Res. Atmos. 119 10425-10440. 
Weuve J, Puett R, Schwartz J, Yanosky J, Laden F and Grodstein F 2012 Exposure to particulate air pollution and cognitive decline in older women; Arch. Intern. Med. 172(3) 219-227.

WHO 2016 World Health Statistics 2016; WHO, Geneva.

Yang T, Sun Y L, Zhang W, Wang Z F and Wang X Q 2016 Chemical characterization of submicron particles during typical air pollution episodes in spring over Beijing; Atmos. Oceanic Sci. Lett. 9(4) 255-262.

Corresponding editor: SuRESH BABU.
Zhao J P, Zhang F W, Xu Y, Chen J S, Yin L Q, Shang X $\mathrm{S}$ and $\mathrm{Xu} \mathrm{L} \mathrm{L} 2011$ Chemical characteristics of particulate matter during a heavy dust episode in a coastal city, Xiamen, 2010; Aerosol Air Qual. Res. 11 299-308.

Zhao X, Zhang X, Xu X, Xu J, Meng W and Pu W 2009 Seasonal and diurnal variations of ambient $\mathrm{PM}_{2.5}$ concentration in urban and rural environments in Beijing; Atmos. Environ. 43 2893-2900 